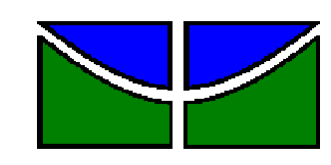

UNIVERSIDADE DE BRASÍLIA

FACULDADE DE EDUCAÇÃO

CURSO DE PEDAGOGIA

\title{
UM RELATO DE VIVÊNCIA COM A EDUCAÇÃO INTEGRAL NUMA ESCOLA PÚBLICA DO DISTRITO FEDERAL: CAIC JUSCELINO KUBITSCHEK DE OLIVEIRA - NÚCLEO BANDEIRANTE - DF.
}

GISELLE CASTRO DE VILLEROY

Brasília - DF

2011 


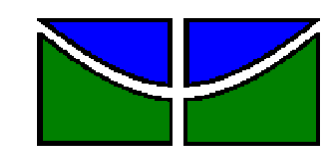

UNIVERSIDADE DE BRASÍLIA

FACULDADE DE EDUCAÇÃO

CURSO DE PEDAGOGIA

\section{UM RELATO DE VIVÊNCIA COM A EDUCAÇÃO INTEGRAL NUMA ESCOLA PÚBLICA DO DISTRITO FEDERAL: CAIC JUSCELINO KUBITSCHEK DE OLIVEIRA - NÚCLEO BANDEIRANTE - DF.}

GISELLE CASTRO DE VILLEROY

Brasília - DF

2011 


\title{
UM RELATO DE VIVÊNCIA COM A EDUCAÇÃO INTEGRAL NUMA ESCOLA PÚBLICA DO DISTRITO FEDERAL: CAIC JUSCELINO KUBITSCHEK DE OLIVEIRA - NÚCLEO BANDEIRANTE - DF.
}

\author{
Trabalho Final de Curso apresentado como \\ requisito parcial para obtenção do título de \\ Licenciado em Pedagogia, à Comissão \\ Examinadora da Faculdade de Educação da \\ Universidade de Brasília.
}

\section{Comissão Examinadora:}

Profa. Dr. ${ }^{a}$ Sônia Marise Salles Carvalho (orientadora)

Faculdade de Educação da Universidade de Brasília

Profa. Dr. ${ }^{\text {a Iracilda Pimentel Carvalho }}$

Faculdade de Educação da Universidade de Brasília

Profa. Dr. ${ }^{\text {a }}$ Teresa Cristina Siqueira Cerqueira

Faculdade de Educação da Universidade de Brasília

Brasília - DF 


\title{
UM RELATO DE VIVÊNCIA COM A EDUCAÇÃO INTEGRAL NUMA ESCOLA PÚBLICA DO DISTRITO FEDERAL: CAIC JUSCELINO KUBITSCHEK DE OLIVEIRA - NÚCLEO BANDEIRANTE - DF.
}

\begin{abstract}
Trabalho Final de Curso apresentado como requisito parcial para obtenção do título de Licenciado em Pedagogia, à Comissão Examinadora da Faculdade de Educação da Universidade de Brasília, sob a orientação da professora Dr. ${ }^{a}$ Sônia Marise Salles Carvalho.
\end{abstract}

\section{Comissão Examinadora:}

Profa. Dr. ${ }^{a}$ Sônia Marise Salles Carvalho (orientadora)

Faculdade de Educação da Universidade de Brasília

Profa. Dr. ${ }^{\text {a Iracilda Pimentel Carvalho }}$

Faculdade de Educação da Universidade de Brasília

Profa. Dr. ${ }^{\mathrm{a}}$ Teresa Cristina Siqueira Cerqueira

Faculdade de Educação da Universidade de Brasília

Brasília - DF 


\section{HOMENAGEM}

Dedico este trabalho:

À minha mãe que sempre me ajudou e me incentivou a estudar e alcançar meus objetivos;

Ao meu pai (in memorian) que se estivesse conosco estaria bastante orgulhoso;

À minhas irmãs - Cristina por ter cursado comigo Pedagogia na Universidade de Brasília e ter me incentivado a seguir este caminho - Michelle por ter sido marcante na minha educação básica em suas aulas de reforço de matemática.

Ao meu marido e meu filho pelo amor, pela confiança, pelo apoio e compreensão;

Ao meu sobrinho George que nasceu junto com meu ingresso à Universidade de Brasília. 


\section{AGRADECIMENTOS}

Agradeço:

A Deus por ter me criado e ter me dado sabedoria para trilhar os caminhos que sonho.

A minha família por participar da minha formação ao longo da minha vida.

Aos professores que tive na Faculdade de Educação, em especial à professora Sônia Marise, que pelo seu exemplo, força, carinho e dedicação me incentivou neste trabalho.

Ao professor Paulo Bareicha de Andrade por ter me apresentado o tema Educação Integral. Aos colegas do curso de pedagogia por ter tornado os dias e as aulas agradáveis durante esses anos.

Meus sinceros agradecimentos! 
"Todas as escolas precisam ser de educação integral, mesmo que não sejam de tempo integral. Trata-se de oferecer mais oportunidades de aprendizagem para todos os alunos.”

Moacir Gadotti 


\section{RESUMO}

Este trabalho tem o objetivo de conhecer e compreender a Educação Integral em uma escola pública do Distrito Federal. Através do conhecimento da vivência e do dia-a-dia da escola, foi possível perceber as diferenças e semelhanças da educação integral do CAIC Juscelino Kubitschek de Oliveira, escola situada na cidade satélite Núcleo Bandeirante do Distrito Federal. Foi possível também fazer, neste trabalho um comparativo entre o programa do governo federal Mais Educação de Educação Integral e o projeto utilizado na escola objeto de estudo.

Para isso foi feita uma análise do Projeto Político Pedagógico da escola, bem como observações em sala de aula, entrevistas com pais, alunos e servidores do CAIC-JKO. A pesquisa bibliográfica baseou-se na leitura de autores da área de Educação Integral, como por exemplo Moacir Gadotti, Jaqueline Moll, Anísio Teixeira, dentre outros.

PALAVRAS-CHAVE: Educação Integral, educação básica, jornada ampliada, educação, políticas públicas de educação. 


\section{SUMÁRIO}

APRESENTAÇÃ

PARTE I

Memorial............................................................................ 4

\section{PARTE II}

INTRODUÇÃO

CAPÍTULO I - REFLEXÕES SOBRE EDUCAÇÃO INTEGRAL NO BRASIL

1.1.

HISTÓRICO........................................................................... 16

1.2.

CONCEITO ............................................................................. 20

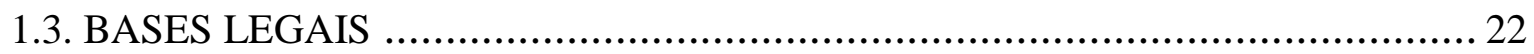

1.4. CONDICIONALIDADES DO PROGRAMA........................................... 25

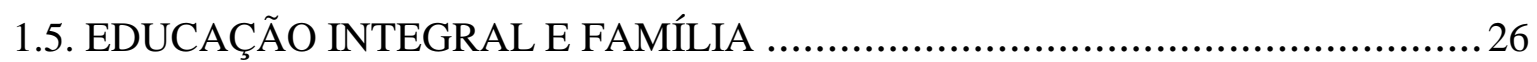

1.6. EDUCAÇÃO INTEGRAL E POLÍTICAS SOCIAIS ................................... 27

CAPÍTULO II - A PRÁTICA DA EDUCAÇÃO INTEGRAL NUMA ESCOLA PÚBLICA DO DF: CAIC JUSCELINO KUBITSCHEK DE OLIVEIRA (CAIC JKO) - NÚCLEO BANDEIRANTE - DF

2.1. BREVE HISTÓRIA DO NÚCLEO BANDEIRANTE................................... 29

2.2. HISTÓRIA E CARACTERÍSTICAS DO CAIC - JKO ................................ 34

2.3. PROPOSTA DE INSERÇÃO DO PROGRAMA NA ESCOLA........................... 38

2.4. REFLEXÕES DO RESULTADO DA PESQUISA NA ESCOLA SOBRE

EDUCAÇÃ̃ INTEGRAL............................................................... 41

2.5. A PERCEPÇÃO DOS PAIS E ALUNOS SOBRE EDUCAÇÃO INTEGRAL E

RESULTADOS DAS OBSERVAÇÕES FEITAS NA ESCOLA...........................43

3. DISCUSSÃO E ANÁLISE............................................................ 47

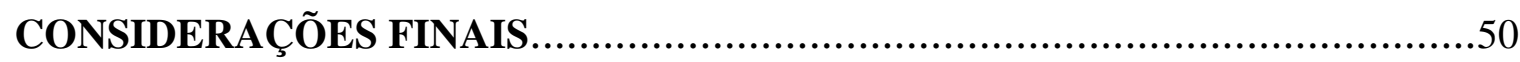

PROJETO DE ATUAÇÃO PROFISSIONAL .................................................. 52

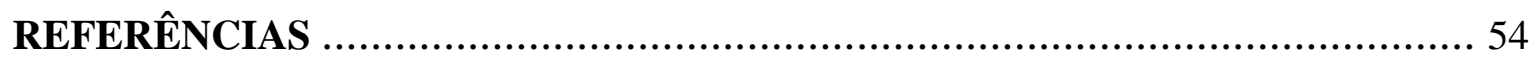




\section{APRESENTAÇÃO}

Este trabalho é a etapa final do curso de Pedagogia, e constitui-se como um dos requisitos acadêmicos para obtenção do título de graduação. Ele se divide em três partes, devido às normas acadêmicas do curso, que são: memorial, ensaio e projeto de atuação profissional.

O memorial é um resumo de toda minha trajetória educativa, incluindo a minha vida anterior à faculdade, o que foi importante na minha vida escolar, e o que me levou ao curso de Pedagogia. Para facilitar a leitura ele está dividido em parágrafos correspondentes a cada ano letivo escolar e, parágrafos com algumas informações relevantes que fizeram parte da minha vida educacional.

A segunda parte, deste trabalho, é o ensaio em si, que procura conciliar as temáticas vivenciadas no projeto 3 e 4 da Faculdade de Educação, que ambos foram sobre o tema Educação Integral, o primeiro aborda conhecimento do tema em teorias e o segundo o conhecimento do tema na prática. Para realização desta monografia foram necessárias várias visitas à escola, colhidas à época dos projetos e também recentemente. Foram feitas entrevistas e coleta de materiais úteis à realização deste estudo, bem como observação ativa.

Esse relato de experiência se divide em três capítulos. O primeiro capítulo aborda o conceito e a história da Educação Integral no Brasil, os fundamentos legais, a forma como funciona na prática a jornada ampliada escolar e por último uma relação da Educação Integral com a família e com as políticas sociais. No segundo capítulo iremos conhecer um pouco da história da cidade satélite do Distrito Federal - Núcleo Bandeirante, conhecer a escola e sua estrutura, perceber como funciona a jornada ampliada, e, por último, é apresentada uma pesquisa feita com pais, alunos e demais atores envolvidos neste processo educativo. O terceiro capítulo fecha com uma análise sobre Educação Integral na teoria e a

prática da escola, ou seja, quais as diferenças que puderam ser percebidas entre um e outro. Para isso utiliza-se do Programa do Governo Federal Mais Educação que é responsável por nortear essa modalidade da educação. 
A terceira e última parte são idéias de um projeto de atuação profissional. Nele pode ser visto minhas intenções, depois de formada, de atuação na área de Pedagogia. São apresentadas algumas opções sobre quais campos da área pedagógica eu gostaria de trabalhar e que tipo de profissional eu gostaria de ser. 


\section{PRIMEIRA PARTE}




\section{MEMORIAL}

Meu processo educativo se deu de forma bastante natural e sem complicações. Cursei toda a minha educação básica em escola pública e geralmente a escola era próxima à minha casa. Sempre tive muitos amigos na turma, meus pais nunca precisaram me obrigar a estudar e quando eu queria tinha ótimos resultados no meu boletim escolar. Desenvolverei parágrafos referentes a cada ano de escola e também parágrafos que falam de assuntos considerados por mim relevantes para o meu processo educacional.

Comecei a estudar com cinco anos de idade, lembro que eu via minhas duas irmãs irem para escola e eu ficava na janela olhando sempre pedindo a minha mãe para eu estudar também, aí ela me dizia que era ainda cedo demais. Lembro que na pré - escola, mais precisamente prézinho, que é como chamavam na época, tinha muitas brincadeiras e muitos desenhos para colorir e eu adorava tudo isso. Quando fiz seis anos de idade não pude ir para a primeira série, tive novamente que fazer o prézinho só que em outra escola que não era muito diferente da anterior. A única diferença é que nela tínhamos uma sala de espelhos aonde íamos para aprender um monte de coisas, como por exemplo, distinguir a mão esquerda da direita. Tive bom êxito nesse período e bom desempenho nas atividades.

Quando fui para a primeira série, contava eu com sete anos de idade e as únicas lembranças que tenho são das primeiras lições de matemática e de português. Minha professora nos colocava sentados no chão da sala em roda, pegava um quadro de papel pardo que tinha sílabas separadas em cartões e, ia nos alfabetizando dessa forma, através da combinação das sílabas. Lembro das continhas de matemáticas armadas no quadro que eu assimilava com facilidade. Não me recordo de ter dificuldades de aprender, pois para mim é como se eu já soubesse de tudo isso.

Na segunda série, minha melhor recordação é da professora, que chamávamos de Tia Zezé, ela gostava muito de mim e me chamava de 'minha florzinha'. Eu era bem comportada e bem dedicada, ela sempre me tomava como exemplo para turma. Gostava de colocar os alunos bagunceiros sentados comigo para ver se eles ficavam quietos. Não me recordo bem do conteúdo que aprendi, mas lembro que em uma ocasião aprendemos como plantar feijão e milho e deixamos uma plantinha de milho na janela da sala, que havíamos plantado e que demos o nome de miliopã. 
Sobre minha terceira série, ela foi bem engraçada. Tinha uma sala no porão do colégio que todos os alunos tinham medo, eles diziam que tinha uma múmia escondida lá. Todos nós morríamos de pavor de ficar lá embaixo e nesse ano minha sala teve que ser no porão porque a escola estava com muitas turmas e tiveram que utilizar as salas de baixo. Talvez por isso, eu tenha tido uma queda no rendimento, mas não foi nada preocupante. A minha professora de artes dessa época era muito nervosa e sempre que ela queria ordem na turma, pegava uma tesoura daquelas mais pesadas e batia na mesa fazendo um barulho ensurdecedor, a maioria dos alunos do colégio não gostava dela.

Quarta série foi um ano novo, novo porque a escola foi reformada e ficou muito bonita, minha sala não foi no porão e nessa época eu morava em frente à escola mesmo. Nesse ano, meu pai faleceu. Lembro que tive algumas faltas, mas a professora Magda, esse era seu nome, entendeu que minhas faltas podiam ser recuperadas. O que mais lembro dessa série, são os trabalhinhos que a professora mandava a gente fazer sobre cada livro que líamos, tínhamos que ler o livro e fazer um resumo e entregar para ela. Nesses trabalhos, eu fazia sempre o que eu mais gostava que eram aquelas capas de trabalhos, as minhas eram sempre as mais bonitas da turma.

Aos 11 anos, após o falecimento do meu pai mudamos da cidade satélite Núcleo Bandeirante e fomos para a Samambaia, lá era tudo diferente, a escola era diferente, os alunos da minha turma de quinta série me tinham como a "riquinha" da classe. Minha aula começava às onze da manhã porque era o período intermediário, e não tinha vaga nos outros horários para mim. Só que isso foi por pouco tempo, porque mudei para outra escola da Samambaia mesmo, para o turno da manhã. A minha $5^{\text {a }}$ série não foi muito boa, passei por três escolas, antes da de turno intermediário havia estudado no Núcleo Bandeirante um mês, e talvez essas mudanças contribuíram para as baixas notas que pela primeira vez tive no meu boletim escolar.

Finalmente, minha mãe resolveu nos colocar, eu e minhas duas irmãs, na escola do Núcleo Bandeirante, que eu havia começado a quinta série. Acho que por isso melhorei meu desempenho novamente. Fiz a sexta série lá, mas morávamos na Samambaia ainda, e tínhamos que pegar ônibus todos os dias. Nossa casa ficava sempre vazia, pois minha mãe estava sempre numa chácara que tínhamos no Bandeirante e nós só voltávamos para a casa pela noite. Acho que no final da sexta série voltamos para o Núcleo Bandeirante, para um 
apartamento. O que mais me marcou desse ano foi um trabalho de ciências que a turma toda fez sobre os seres vivos, foi interessante porque a professora queria que levássemos os exemplares de cada ser vivo, e meu grupo ficou com os crustáceos, tivemos que comprar no mercado uma lagosta para levar.

Na sétima série, senti um pouco porque eu não tinha costume de estudar pela manhã, só tinha estudado um pouco da quinta. Minha casa era muito longe da escola, pois minha mãe resolveu que tínhamos que mudar para a chácara que tínhamos no Bandeirante. Eu faltava muito, não gostava de ir para as aulas de educação física, mas mesmo assim tinha notas suficientes para ser aprovada nas outras matérias. Minha professora, num gesto de intolerância e ignorância me reprovou em educação física por falta e por causa de dois bimestres, e ela não tinha muita razão, porque eu acho que nesse ano também teve greve e nem a escola estava cumprindo com suas obrigações.

Reprovei a sétima série e fui fazer novamente, mas dessa vez no turno da tarde. Como eu já sabia os conteúdos, afinal reprovei por causa da Educação Física, tirava sempre boas notas. Lembro que eu sentava na parte superior do meio da sala e todos os meninos gostavam de conversar comigo, eu era a aluna bagunceira e estudiosa. No recesso do meio do ano conheci a pessoa que posteriormente terá total importância na minha vida. Ele fazia parte de um grupo de amigos recém conhecidos que iam à minha casa fazer cultos evangélicos. Eu e minhas irmãs estávamos freqüentando uma Igreja Evangélica e me distanciei um pouco dos estudos.

Terrível, foi para mim a oitava série. Mudei de escola e todos os meus amigos da escola anterior não estavam na minha turma. Eu não me esforçava para fazer amizades e no começo foi meio estranho. Fiz amizade com duas meninas e me senti menos deslocada. Comecei com um desempenho ruim, faltava muito. Neste, ano tive meu primeiro namorado, ele fazia parte do grupo de amigos que ia a minha casa no ano anterior. Ele me incentivava muito a estudar. De tanto ele falar, comecei a me esforçar e tirar ótimas notas, principalmente em matemática. Meu primeiro namoro foi muito rápido, falaremos sobre essa história mais adiante.

Entrei para o segundo grau, no ritmo da oitava série, faltava muito e não conhecia ninguém na turma. Meu primeiro ano do ensino médio era para ser turbulento, mas graças a Deus e a um professor de História não foi. Esse professor falando da primeira reunião do 
conselho de classe da turma, da qual ele era conselheiro, disse para todos na turma que eu fui destacada como aluna faltosa. Desse dia, resolvi não faltar mais e minhas notas subiram muito a ponto de eu concorrer com os dois melhores alunos da turma. Eu tirava ótimas notas em matemática, em história, em inglês que era a principal razão das notas baixas dos demais alunos. Esse mesmo professor colocou a turma organizada de modo que tínhamos lugar marcado, com isso fiz amizade com uma menina chamada Fabiana que iria no decorrer do ano me apresentar a minha futura melhor amiga da escola.

Segundo ano do segundo grau, caí um pouquinho nas notas. Não tínhamos professor de Física. A escola estava uma bagunça e eu novamente estava buscando outras coisas, que me faziam desviar a minha atenção aos estudos. Minha melhor amiga - Eliane, que a Fabiana do primeiro ano me apresentou - estava em outra turma. Mas, conheci a Érika representante da turma - conversávamos e ríamos a aula inteira. Mesmo assim, continuei com ótimos rendimentos em matemática, no segundo bimestre eu já tinha nota suficiente para o ano todo. No final desse ano, comecei a me interessar por música e os estudos me importavam menos ainda.

Finalmente o terceiro ano do segundo grau. Minha melhor amiga, a Eliane, estava na minha turma juntamente com a Fabiana, tinha alguns alunos do primeiro e do segundo ano, inclusive aquele que era um dos melhores da sala no primeiro ano. Era o Víctor, fizemos uma grande amizade no segundo ano e depois no cursinho pré - vestibular. No meu último ano de escola eu faltava muito, pois sempre estava em shows de rock com minha amiga Eliane, a irmã dela e minha irmã Isabel Cristina. Conclui o Ensino Médio de forma razoável, com a exceção de matemática que como sempre era marcada com ótimas notas. Meu professor de matemática, como os dois dos anos anteriores, gostava muito de mim e sempre deixava recadinhos com palavras de incentivo nas provas. O último que ele deixou, na última prova que fiz com ele foi: “É isso aí, menina. Você vai longe”. Concluí meus estudos básicos não da forma como eu deveria, mas assim o fiz da maneira que pude.

Assim que terminei o Ensino Médio fiz vestibular para História na UEG Universidade Estadual do Goiás - e, claro, não passei. Não tinha preparo nem conhecimento suficiente, a minha escola de ensino médio não me preparou para o vestibular, as minhas ótimas notas em matemática e outras matérias não eram suficientes para concorrer com o mundo lá fora. No ano seguinte, com dezenove anos, passei num 
concurso do IBGE, temporário, para trabalhar no CENSO 2000 como supervisora, foi uma experiência muito boa e abriu portas posteriormente, trabalhei em outra pesquisa indicada por eles que também foi muito enriquecedora. Nesse ano fiz meu primeiro cursinho prévestibular e também o primeiro vestibular da Universidade de Brasília e não fui aprovada.

Em 2001, fiz novamente um cursinho pré-vestibular. Dessa vez no Cursinho Alub lá ensinavam de verdade e estimulavam o aluno a conseguir aprovação. Minha irmã Isabel Cristina, a colega Eliane e o Víctor do terceiro ano estudaram comigo. A gente acordava muito cedo para ir às aulas, quando eu voltava à minha casa só tinha vontade de dormir. Sempre no início do semestre eu começa empolgada, mas depois desanimava. Fiz novamente o vestibular e nada, tentei cursos como arquivologia, letras, mas não consegui aprovação.

Em 2002, o ano foi diferente. Resolvemos novamente eu, minha irmã Cristina e a Eliane fazer outro cursinho no Alub. Eu me mantinha no mesmo desânimo de estudar e na vontade de ser aprovada na UnB de todo jeito. Minha irmã resolveu neste semestre tentar o curso de Pedagogia, e dessa vez ela me surpreendeu bastante. Cristina sempre foi muito inteligente, muito mesmo, mas sempre teve preguiça de estudar e dessa vez ela estudava todos os dias de tarde e de noite. Eu passava em frente ao quarto de estudos que a gente tinha em casa e estava ela lá o tempo todo de olhos nas apostilas, às vezes tirava um cochilo para descansar, ali mesmo por cima dos livros, afinal a gente acordava muito cedo. Só que ela não parava, estudou muito e assim fez o exame vestibular e foi aprovada no curso de Pedagogia, foi a terceira colocada com uma nota excelente, ela só não passaria com esse resultado acho que nos três primeiros cursos mais procurados da Universidade, mas, para o restante dos cursos tinha argumento suficiente para isso.

Com a aprovação da minha irmã, me empolguei. Resolvi fazer o quarto cursinho pré-vestibular e dessa vez fiz sozinha no turno noturno, minha irmã já era aluna da UnB e a minha amiga Eliane tinha desistido de tentar. Freqüentei as aulas e da mesma maneira que os outros eu não estudava em casa nas horas vagas e para mim era complicado porque ou eu estava trabalhando e fazendo cursinho ou estava fazendo cursinho e estudando para concursos públicos.

Dei uma pausa em tudo, parei para respirar, fiquei uns tempos sem fazer cursinho, sem estudar, estava cansada. Mas, não tinha desistido do meu sonho. Li muitos livros de 
literatura, tive alguns empregos rápidos e relaxei em relação aos estudos. Minha irmã já estava quase no sexto semestre e eu nada. Resolvi então, tentar novamente o vestibular para Pedagogia. Estudei com calma, descansava, lia, tinha uma vida normal e fiz a prova do vestibular da UnB. Só que não fui aprovada porque apesar de minha nota ser suficiente, não consegui nota na redação.

Então, me animei mesmo, percebi que a chave de tudo era o equilíbrio. Consegui nota no vestibular passado e para mim só faltava treinar um pouco redação. E foi o que eu fiz, dei uma revisada na matéria e passei um semestre todo escrevendo redação. Estava entusiasmada, às vezes eu ia com minha irmã assistir aula na UnB e era isso que eu queria mesmo. Fiz o vestibular novamente e obtive êxito - fui aprovada. Escrever sobre isso até me emociona, a sensação de ver meu nome na lista dos aprovados no vestibular de uma das melhores Universidades do país é inexplicável.

Abro aqui agora um parêntese muito importante. Trata-se de uma personagem muito especial e importante nesse final de história. Trata-se da Gaia Maria. Uma gatinha que a Cristina pegou para criar que de tão pequenininha era do tamanho do meu celular. Lembro que minha irmã a levava lá para o meu quarto quando eu estava estudando e até me tirava atenção. Ela colocava a Gaia em cima da cama e eu sempre dava uma pausa para brincar com ela. O ruim de tudo isso é que Gaia Maria não vai poder acompanhar minha formatura porque infelizmente ela faleceu dias antes de eu começar este memorial. Fiquei muito triste e fica aqui neste parágrafo minha homenagem a ela.

Desculpe, preciso abrir aqui outro parágrafo, quer dizer dois parágrafos adicionais. O primeiro: preciso destacar que além da Gaia tem alguém que faz parte da minha vida na UnB, é o meu sobrinho George. Quando eu entrei na UnB ele nasceria quatro dias depois. Hoje ele está com cinco anos e já é um rapazinho, participou muito da minha vida acadêmica. Hoje, como futura pedagoga observo muito a educação e a escola dele. Ele é filho da minha irmã mais velha, a Michelle.

Como disse precisava de mais um parágrafo, esse é o da minha mãe, sempre presente nos meus estudos, apoiando, incentivando. Uma das coisas que mais me deu força para ir atrás dos meus sonhos, foi ver o sorriso de satisfação da minha mãe quando a Cristina lhe falou que havia sido aprovada no vestibular da UnB. Para mim foi vital, eu precisava ver aquele sorriso de novo, por isso corri atrás até conseguir. Minha mãe mesmo 
sem poder financiou meus estudos, ela sempre foi muito compreensiva, preferia que a gente estudasse, e fazia questão de cuidar da casa sozinha. Assim podíamos dedicar nosso tempo aos estudos. Quando eu estudava das nove da manhã às onze da noite, que era como eu fazia, minha mãe estava sempre com o café da manhã pronto, o almoço, o jantar. Tudo isso contribuiu e foi decisivo para eu chegar até aqui.

Vida nova, semestre novo, meu primeiro dia de aula na UnB chegou. Inacreditável, parecia um sonho! Eu enxergava a UnB como algo inatingível, uma muralha que eu nunca conseguiria romper. Minha irmã já estava no sétimo semestre de Pedagogia e como sempre me acompanhara em tudo, foi comigo até a sala do primeiro dia de aula, me mostrou onde era e ficou na porta me esperando entrar. Após entrar e sentar acenei e ela se despediu, ficou de me buscar depois da aula, pois a aula dela era no prédio da Faculdade de Educação, enquanto que a minha era num dos pavilhões da Universidade e ambos não são muito pertos. Não lembro dos outros dias de aula dessa semana, mas sei que foi uma experiência incrível.

Satisfeita por conseguir ingressar na $\mathrm{UnB}$, algo dentro de mim me inquietava. Eu estava adorando o curso, mas percebia que faltava algo. A Cristina teve que se ausentar um semestre devido a um concurso que tinha sido nomeada. Fizemos antes algumas disciplinas juntas, a UnB entrou de greve e novamente tive que repensar minha vida. Eu precisava como minha irmã, passar em um concurso público, a vida acadêmica na UnB não é fácil de manter. São muitos livros, passagens, alimentação tudo isso requer dinheiro e a Cristina manteve bem isso e eu não podia depender dela sempre, minha mãe também me ajudava muito. Devidos a alguns problemas minha ida a UnB estava cada vez mais comprometida, problemas de saúde, dificuldades financeiras, etc. Eu estudava em casa para concursos, naquela busca igual a do vestibular e nada conseguia. Sem trabalhar, muitos gastos, pouco dinheiro, tudo complicava.

Procurava estágio nada conseguia, trabalhei outra vez no IBGE em 2007. Fiz novamente um concurso temporário e fui aprovada, trabalhei os seis meses e fiquei de novo com dificuldades de me manter na faculdade. Procurava estágio na área de Pedagogia, fazia entrevistas e nada. Fiz uma entrevista na CAESB - Companhia de Saneamento Ambiental do Distrito Federal - e só não fui chamada porque o semestre que eu estava não era 
suficiente, o chefe de lá ficou de me chamar caso precisasse mais adiante e não perdi as esperanças.

Em 2008 o ano foi novo e marcante, eu já estava no sexto semestre. Entre mudanças de turno das aulas comecei no matutino, passei para o vespertino, fui para o noturno e finalmente voltei para o diurno, pois não vi promessa de trabalho então não teria problema estudar pela manhã. Já tinha iniciado o semestre e o chefe da CAESB me ligou falando sobre o estágio se eu ainda tinha interesse, pois o semestre que eu estava cursando já era suficiente. Falei que queria e iria lá tratar dos papéis, só que tinha um problema, teria que mudar como das outras vezes novamente o horário das aulas, mudei, tentei não prejudicar as aulas e fui estagiar na CAESB.

A CAESB para mim foi uma experiência e tanto lá conheci o trabalho de docência de perto, nós dávamos aula de Educação Ambiental para alunos do Ensino Fundamental, fomos a diversas escolas, como por exemplo, em Ceilândia, Sobradinho, Planaltina, Estrutural. Tudo que levávamos para a sala de aula, nós os estagiários que criávamos, trabalhamos muito com reciclagem de resíduos sólidos. Nesse período, reencontrei meu primeiro namorado, o da oitava série, foi emocionante. Tínhamos perdido o contato desde os meus 15 anos, raras vezes nos encontramos ao acaso na rua, mas nos cumprimentávamos só de longe. Eu sempre fui bastante quieta, nunca misturei escola com namoro e também não fiz isso na faculdade, eu sabia que ia para estudar e namoro nunca atrapalhou meus estudos eu sempre pensava em casar e ter filhos depois de estar formada, esse era o meu jargão.

Só que o coração falou mais alto, eu e o Israel - esse é o seu nome - passamos a nos ver com freqüência e voltamos a namorar. Ele estava no último semestre de Radiologia Médica e trabalhava perto do meu serviço. Um verdadeiro príncipe! Novamente como na oitava série, ele me incentivou a estudar mais e a me dedicar aos estudos, eu andava meio solta em relação a eles. Talvez o estágio estivesse me desgastando demais. Resolvi então, depois de seis meses, sair da CAESB e enfrentar todas as dificuldades financeiras de novo. Falei para todos lá e para a minha mãe que eu não podia mais comprometer meu tempo com aquilo e ganhar tão pouco, contei a ela que ia sair para me dedicar mais aos concursos públicos. Minha mãe como sempre, me apoiou. 
Fiquei uns meses estudando, em casa, não fiz cursinho preparatório. O Israel me incentivou muito, minha mãe, minha irmã também, que a essa altura já estava no terceiro concurso que havia sido nomeada. Resolvi, então, me inscrever num concurso público que aparentemente não parecia ser legal o trabalho. Pedi isenção de taxa e fiquei sabendo uma semana antes da prova que eu tinha sido isenta. Estudei essa semana inteira, o dia todo, Israel chegava à minha casa à noite e via os livros a minha volta e me elogiava sempre e, isso me empolgava ainda mais. Fiz a prova, fui aprovada, fiquei muito feliz, igual à vez do vestibular, demorou uns meses para sair a nomeação e comecei a trabalhar, tive que mudar de novo o semestre, mas não afetou minha vida acadêmica.

Após mais essa realização, percebi que eu precisava agilizar minha formatura e me dedicar mais à minha faculdade tão sonhada. Aconteceu algo inusitado, cada dia que passava eu percebia que faltava mais alguma coisa na minha vida e então eu e o Israel resolvemos nos casar. De data marcada, outra surpresa: o fruto do nosso amor já estava encomendado e eu estava grávida de quase dois meses. Não acreditei, eu queria ter filhos depois de formada. Mas fiquei feliz. Natanael hoje está com um ano e 5 meses, dei uma freada na faculdade, mas retomei. Hoje estou muito feliz com a minha família, eles são muito importantes para mim. Quero ver o sorriso deles me assistindo lá na minha formatura, isso me anima e me impulsiona a continuar lutando pelos meus sonhos.

Relatando um pouco mais sobre a minha graduação, algumas disciplinas que cursei foram as minhas preferidas como Sociologia da Educação, Educação Ambiental, Educação Matemática, Oficina Vivencial, Educação do Campo, Psicologia da Educação, Pesquisa em Educação, Fundamentos da Arte na Educação. Tive excelentes professores e aprendi muito. $\mathrm{Na}$ minha memória ainda ficará a lembrança do primeiro dia de aula, o período de adaptação à universidade, os amigos que fiz - devo não esquecer a minhas principais amigas Jaqueline e Geórgia, os livros que li, as atividades que realizei, enfim guardarei tudo com muito carinho.

Contada minha história, preciso dizer aqui minha escolha pelo curso de Pedagogia e pelo tema desta monografia. Na verdade eu não tinha nada em mente, nunca achei que tivesse uma vocação, lembro que quando criança eu falava que queria ser professora. Dos cursos que tentei ingressar na UnB talvez por nenhum outro eu me interessasse tanto. Fiz Pedagogia primeiramente porque minha irmã me influenciou. Mas, me mantive, 
principalmente por gostar e me identificar com o curso. Momentos bons, interessantes e descontraídos tive na Faculdade de Educação. Muito aprendizado, muitos exemplos bons que devem ser levados adiante. Enfim, uma percepção de que a Pedagogia é a ciência mais humana de todas. Ser uma pessoa, mais crítica, mais confiante, mais determinada, mais conhecedora do mundo da educação, mais compassiva foi o que a Pedagogia me ensinou nesses anos. Sobre o tema que escolhi, na verdade fiquei meio perdida por tantas mudanças na minha vida acadêmica e pessoal.

Tantas idas e vindas, saí do fluxo regular e comecei a cursar disciplinas que não eram do meu semestre, muitos trancamentos e me deparei com projetos 3 e 4 (disciplinas obrigatórias da Faculdade de Educação) sobre Educação Integral. Sempre quis fazer minha monografia sobre um tema que me instigasse que me chamasse atenção e na Educação Integral achei isso, primeiro um tema que não é o que o sentido da palavra diz, conhecer e compreender que essa modalidade de ensino não diz respeito apenas à jornada ampliada, e que o conceito, como veremos adiante, é bem mais amplo, foi peça chave para a escolha do tema. 


\section{SEGUNDA PARTE}




\section{INTRODUÇÃO}

Este presente trabalho é um estudo exploratório no Centro de Atendimento Integral à Criança Juscelino Kubitschek de Oliveira (CAIC-JKO) localizado na cidade satélite Núcleo Bandeirante do Distrito Federal, situada a 15 quilômetros do Centro de Brasília. O estudo busca conhecer e analisar a educação integral do CAIC JKO. Para isto é feita uma abordagem conceitual e histórica sobre educação integral, com base na legislação vigente e uma colocação sobre métodos e relação da educação integral com a família e com as políticas sociais.Posteriormente é narrada a história do Núcleo Bandeirante e da escola para enfim explicar o que acontece na prática no CAIC no que tange a métodos, Projeto Político Pedagógico (PPP), problemas que a mesma enfrenta, opinião dos alunos, pais e professores na experiência e por último a análise dos conceitos de educação integral e a educação integral da escola, com um comparativo com o Programa de Educação Integral Mais Educação, projeto que tem dado certo para as escolas que aderiram ao programa. 


\section{CAPÍTULO 1 - REFLEXÕES SOBRE EDUCAÇÃO INTEGRAL NO BRASIL}

\subsection{HISTÓRICO}

Neste capítulo é feita uma reflexão sobre a história, o conceito, as bases legais, as condicionalidades e a relação da família e das políticas sociais com a Educação Integral. Começaremos pelo histórico e para facilitar o seu entendimento, dividiremos a história da Educação Integral em quatro períodos. O primeiro começa na década de 40 e se estende até a década de 70 com destaque para Anísio Teixeira, o segundo é o período do Regime Militar de 1971 a 1981, o terceiro de 1982 a 1994 onde destacamos o governo do então presidente do Brasil Fernando Collor de Melo com destaque aos CAICs, CIEPS e CIACS e por último o ano de 1994 aos dias atuais.

Começamos então a partir da década de 40 do século passado, iniciamos com a participação de Anísio Spínola Teixeira, jurista, educador e escritor brasileiro que teve bastante importância para a educação no Brasil bem como para a Educação Integral. Anísio Teixeira exerceu várias funções político-profissionais mediadas por funções públicas, exercidas, inicialmente, na direção da Inspetoria de Ensino, na cidade de Salvador no Estado da Bahia. Foi nessa época que ele implantou o Centro Educacional Carneiro Ribeiro (CECR), conhecido também como "Escola-Parque". Tal instituição seria responsável pela educação tanto de crianças como também de jovens até 18 anos.

O Centro Educacional Carneiro Ribeiro (CECR) funcionava da seguinte forma: havia quatro "Escolas-Classe" e uma "Escola-Parque" centralizada entre as escolas-classe. $\mathrm{Na}$ primeira, funcionariam as aulas ditas convencionais e na segunda, a escola-parque, seriam ministradas atividades no período contrário de artes, jogos, recreação, ginástica, teatro, música, dança, etc.

Anísio Teixeira foi um educador comprometido com a qualidade da educação e para isso tinha o sonho de implantar o projeto do CECR em outras áreas do Estado da Bahia, só que infelizmente seu desejo não se realizou na época. Posteriormente, quando diretor do Instituto Nacional de Estudos Pedagógicos (Inep) do Ministério da Educação (MEC), Teixeira conseguiu ver parte do seu sonho se realizar na então capital brasileira, Brasília. 
Na década de 60, Brasília surgia, Anísio Teixeira ao preparar o plano educacional da capital, resolveu colocar em prática novamente seu sonho que mais uma vez se cumpriria apenas em parte. Para ele era necessário construir na capital 28 Escolas-Parque que seriam erguidas nas superquadras do Plano Piloto. Tal projeto não foi posto todo em prática, pois o Projeto de Educação Integral de Anísio Teixeira não foi adiante e apenas algumas escolas foram construídas. A primeira Escola-Parque a ser construída, e a única completa, foi a da entrequadra 307/308 Sul que coincidiu com o dia da inauguração de Brasília.

Anísio Teixeira desejava que seu projeto implantado em Brasília servisse de modelo educacional para todo o País, pois de acordo com as novas exigências vigentes a sociedade precisava de uma escola que fosse completa e integral, que principalmente visasse um ensino global e não apenas fragmentado como os demais implantados no resto do País. De acordo com (Pereira e Rocha, 2011), Teixeira queria uma escola que fosse capaz de:

(...) atender a necessidades de ensino e educação, e, ao mesmo tempo, à necessidade de vida e convívio social. Não se tratava apenas de uma escola, mas de um centro de educação comparável a uma verdadeira 'universidade infantil' (PEREIRA \& ROCHA, www.faced.ufu.br/colubhe06/.../457EvaWaisros_LuciaRocha.pdf . Acesso em 20/01/2011.)

Faremos agora uma breve passagem pelos anos de 1971 a 1981, época da implantação do Regime Militar no Brasil. Pegamos essa década porque temos acontecimentos que marcam a história da educação brasileira. Sabemos que o período do Regime Militar na verdade ocorreu de 1964 e se estendeu até 1985, mas falaremos principalmente da década acima.

No período militar a Educação Integral não ocupa muita importância no cenário brasileiro, uma vez que letrar significava conscientizar. Esse período turbulento traz consigo a criação da segunda Lei de diretrizes e Bases da Educação Nacional, considerando a Lei 4024/61 como sendo a primeira. Foi publicada em 11 de agosto de 1971, durante o regime militar pelo presidente Emílio Garrastazu Médici, a segunda LDB, a Lei 5692/71 que traz no corpo de seu texto dentre outras coisas a obrigatoriedade do ensino de $1^{\circ}$ grau dos 7 aos 14 anos, onde na lei anterior só obrigava o primário. 
Já o período que segue o Regime Militar é marcado por grandes tentativas de implantar o ensino integral, tais tentativas foram bem sucedidas. Nesse período destacamos os governos de Leonel Brizola no Rio de Janeiro e do Governo Collor.

No Rio de Janeiro, por volta de 1983 foram criados os Centros Integrados de Educação Pública (CIEPS), tais centros de educação integral à criança são baseados nas idéias de Anísio Teixeira.

Darcy Ribeiro cria os CIEPS com a idéia principal a não reprovação. Os complexos escolares deveriam ter sala médica e odontológica, bibliotecas, quadras de esporte, refeitório. Na tentativa de banir com a reprovação, Darcy Ribeiro cria uma proposta pedagógica em que a avaliação não é feita por provas e sim por objetivos. Caso os objetivos não fossem alcançados pelos alunos durante um ano letivo o professor voltaria a trabalhar o mesmo assunto no ano seguinte.

Já no Governo de Fernando Collor (1990-1932) são criados os Centros Integrados de Atendimento à Criança (CIACS), na verdade estes são os CIEPS que ganharam um caráter mais assistencial e trocou de nome. Leonel Brizola contribui para o projeto. Collor pretendia construir em seu governo cerca de 5 mil estabelecimentos, mas foi deposto em 1992, dando término ao seu governo.

O primeiro CIAC construído foi o da cidade satélite Paranoá, localizada no Distrito Federal, foi inaugurado em 1991. Tais centros atendiam cerca de 800 crianças e tinham serviços como educação escolar, saúde, cultura, esporte, creche, educação para o trabalho, proteção especial à criança e desenvolvimento comunitário. Tanto os CIEPS quanto os CIACS eram escolas de horário integral, ou seja, os alunos deviam permanecer na escola em tempo integral para que as atividades fossem realizadas. Atualmente os CIACS levam o nome de CAICS. No governo de Itamar Franco (1992-1994) os CIACS passaram a ser Centros de Atenção Integral à Criança (CAICS) que mudou apenas de nome.

No mesmo período, em São Paulo foi criado o Programa de Formação Integral à Criança (PROFIC), só que este projeto não apareceu tanto. Tratava-se de um convênio firmado entre o governo de São Paulo e as prefeituras para atender crianças além do período do turno diário.

Passado esse período, falaremos agora da fase Fernando Henrique Cardoso (19942002). Em 2002, em São Paulo são instituídos os CEUS, projeto diferente dos anteriores, 
mas que também era voltado para famílias mais carentes. Os Centros Educacionais Unificados (CEUS) foram criados pela Secretaria Municipal de Educação da Prefeitura de São Paulo. Localizados na periferia, os CEUS se dedicam à educação infantil e fundamental, à prática de esportes e contribuem para o desenvolvimento das comunidades locais. Busca também um desenvolvimento integral da criança e proporciona as comunidades locais equipamentos públicos de lazer, cultura, tecnologia e atividades esportivas. Segundo (Gadotti, 2009) os CEUS:

O projeto dos Ceus foi concebido, desde sua origem, como uma proposta intersetorial, somando a atuação de diversas áreas, como: meio ambiente, educação, emprego e renda, participação popular, desenvolvimento local, saúde, cultura, esporte e lazer. (GADOTTI, 2009).

Falaremos agora do período do Governo Luís Inácio Lula da Silva. É nesse período que vamos ter a implantação do Programa de Educação Integral Mais Educação, mais precisamente no ano de 2007.

O Programa Mais Educação foi criado pela Portaria Interministerial n 17/2007 com coordenação da Secretaria de Educação Continuada, Alfabetização e Diversidade (SECAD/MEC), em parceria com a Secretaria de Educação Básica (SEB/MEC) e com as Secretarias Estaduais e Municipais de Educação. Sua operacionalização é feita por meio do Programa Dinheiro Direto na Escola (PDDE), do Fundo Nacional de Desenvolvimento da Educação (FNDE).

Tal projeto tem o objetivo de melhorar o ambiente escolar e a princípio atende prioritariamente as escolas que apresentam baixo Índice de Desenvolvimento da Educação Básica (IDEB), é uma estratégia do Governo Federal para incentivar a ampliação da jornada escolar e a organização do currículo nos moldes da educação integral. O programa entrou em vigor no início de 2008 com a participação de 1.380 escolas públicas de todo o Brasil e a meta é atender mais de 10.000 escolas entre estados e municípios brasileiros. O Programa Mais Educação visa diminuir as desigualdades educacionais e busca valorizar a diversidade cultural brasileira.

Faremos agora uma passagem sobre os principais pontos da Educação Integral no Distrito Federal na década atual. Em 2007, o médico e político Alceni Guerra assume a Secretaria de Educação do Distrito Federal. Ex-prefeito da cidade de Pato Branco - Paraná, 
Guerra implantou lá um programa de educação integral eficiente que contava com a participação da comunidade, alunos e empresários da região. Foi incumbido a ele o dever de implantar o mesmo projeto no DF, tal projeto não obteve êxito da forma planejada e não funcionou como no Paraná.

Atualmente, algumas escolas do DF utilizam o Programa Mais Educação como projeto de Educação integral e outras utilizam o Programa Escola Modelo. Tal programa foi criado no governo de José Roberto Arruda com o fim de enriquecer o conhecimento dos alunos e proporcionar uma formação humanística aos mesmos. As aulas são ministradas em período integral em que pela manhã eles estudam disciplinas do currículo escolar com professores, almoçam na escola e a tarde fazem atividades com monitores mantidos pelo governo como música, xadrez, canto coral, artes visuais, teatro, aulas de primeiro socorros, ética, esportes, etc.

O Programa Escola Modelo funcionou algum tempo no CAIC Juscelino Kubitschek de Oliveira (CAIC - JKO), mas que hoje utiliza programa próprio da escola. Tal escola é objeto de estudo em questão e abordaremos com mais detalhe adiante. Algumas outras escolas do DF também utilizam a Escola Modelo como é o caso de duas no Plano Piloto, duas no Riacho Fundo e uma em Planaltina.

\subsection{CONCEITO}

A Educação Integral é por muitos, mesmo até entre o meio educacional, entendida de forma incorreta. Ela pressupõe totalidade, integralidade e não faz apenas uma relação a tempo como muitos pensam. A idéia de Educação Integral equivocada que temos é aquela em que a criança vai para a escola, ficando lá pela manhã e a tarde apenas para passar tempo e para seus pais poderem trabalhar. De acordo com (Moll, 2000) a educação integral:

(...) pressupõe escola pública, de qualidade e para todos em articulação com espaços/políticas/atores que possibilitem a construção de novos territórios físicos e simbólicos de educação pública. (MOLL, 2000, p. 12)

$\mathrm{Na}$ verdade, Educação Integral diz respeito a um conjunto de fatores que estão ligados ao desenvolvimento total da criança. Totalidade aqui pressupõe completude, inteiro. 
Segundo o Moderno Dicionário da Língua Portuguesa Michaelis (www.michaelis.uol.com.br, acessado em 11/05/2011), a palavra totalidade significa "aquilo que é completo", "total". Dito assim, a criança teria na escola integral um desenvolvimento completo, capaz de ampliar suas habilidades físicas, intelectuais e morais com um reconhecimento de suas dimensões afetiva, física e ética.

Segundo o Decreto n 7083 , de 27 de janeiro de 2010 que dispõe sobre o Programa Mais Educação, o conceito de jornada ampliada leva em consideração o tempo que a criança passa na escola que deve ser superior a sete horas diárias e durante todo o período letivo, conforme podemos ver:

(...) considera-se educação básica em tempo integral a jornada escolar com duração igual ou superior a sete horas diárias, durante todo o período letivo, compreendendo o tempo total em que o aluno permanece na escola ou em atividades escolares em outros espaços educacionais. (http://www.planalto.gov.br/ccivil 03/Ato20072010/2010/Decreto/D7083.htm visitado em 21/04/2011)

A Educação Integral abrange também, uma maior proximidade com os diversos atores, parceiros e espaços da cidade. Falamos de uma educação capaz de ensinar, conviver e respeitar, é aquela que busca um diálogo constante entre escola, família, comunidade e cidade. Dessa forma, (Gadotti, 2009) nos diz que:

A escola pública precisa ser integral, integrada e integradora. Integrar ao Projeto Eco-Político-Pedagógico da escola as igrejas, as quadras de esporte, os clubes, as academias de dança, de capoeira e de ginástica, os telecentros, parques, praças, museus, cinemas etc, além de, universidades, centros de estudos, ONGs e movimentos sociais; enfim, integrar o bairro e toda municipalidade (GADOTTI, 2009, p.32-33).

Pensando assim, a Educação Integral não é um ato restrito às paredes fechadas das escolas. Ele pode e deve se estender por toda a sua localidade. $\mathrm{O}$ aluno deve ser capaz de interagir com os diferentes meios que o cerca e, da mesma forma, a cidade deve ter esse papel. É esse o conceito de Educação Integral, um conceito que busca uma educação global e integrada, as disciplinas devem ser integradas e complementares, a integração cidadealuno deve acontecer, os pais devem participar da vida escolar e da escola, caso contrário não há educação integral. A educação integral não pode ser confundida com horário integral, tempo integral ou a jornada integral, ela deve englobar um sentido mais amplo. 
Assim, Educação Integral é educação completa que busca o desenvolvimento integral da criança e tal desenvolvimento alia os conteúdos da escola com a interação da família, da comunidade, das organizações sociais, da cidade. Sem isso não há educação integral e sim escola de tempo integral que é aquela em que o aluno estuda em dois turnos, só que os conceitos de integralidade não fazem parte de seu modelo educativo.

Com isso, educação integral requer uma visão holística, ou seja, não deve ser reduzida ao mero ensino escolar regular, conforme (Gadotti, 2009):

(...) o que se propõe à educação integral é a integralidade, isto é, um princípio pedagógico onde o ensino da língua portuguesa e da matemática não está separado da educação emocional e da formação para a cidadania. (GADOTTI, 2009, p. 41)

Vale lembrar também que a jornada escolar ampliada é um conjunto de ações que visam à melhoria do ensino e também do aprendizado do aluno, busca diminuir os índices de evasão, reprovação e distorção idade/série tão presentes na realidade escolar brasileira. Assim, cabe a educação integral inserir alunos das camadas sociais menos favorecidas no mundo dos esportes, das letras, da informática, da música, da dança, atividades essas que a maioria não teria acesso se não fosse através desta escola.

A jornada escolar ampliada tem por objetivos promover um diálogo entre os conteúdos escolares e os saberes das comunidades locais; aproximar professores, alunos e suas famílias; combinar ensino com políticas sociais que visem à promoção da saúde, da alimentação saudável, da cultura, dos direitos humanos, da prática de esportes.

\subsection{BASES LEGAIS}

A Educação Integral têm seus fundamentos inicialmente na Constituição da República Federativa do Brasil de 1988 que em três artigos preconiza o ensino integral. O artigo 205 deixa claro a responsabilidade do Estado e da família para com a educação e ressalta o significado da mesma, a ser o desenvolvimento pleno da pessoa, seu preparo para o exercício da cidadania e sua qualificação para o trabalho. No artigo 206 é citada a 
importância do ensino a ser oferecido de forma igual aos alunos no acesso e na permanência na escola.

O artigo 227 da Constituição Brasileira também dá indícios da necessidade de uma educação integrada, a saber:

Art. 227 - É dever da família, da sociedade e do Estado assegurar à criança, ao adolescente e ao jovem, com absoluta prioridade, o direito à vida, à saúde, à alimentação, à educação, ao lazer, à profissionalização, à cultura, à dignidade, ao respeito, à liberdade e à convivência familiar e comunitária, além de colocá-los a salvo de toda forma de negligência, discriminação, exploração, violência, crueldade e opressão.

A nossa legislação é bastante preocupada com o desenvolvimento e o bem-estar de nossas crianças. A lei 8069/90 - Estatuto da Criança e do Adolescente - defende uma educação preocupada com os valores culturais, artísticos e históricos próprios do contexto da criança e do adolescente. Coloca a família como cerne do processo educativo e valoriza em suas entrelinhas a educação integral nas escolas quando nos diz que:

Art. 53 - A criança e o adolescente têm direito à educação, visando ao pleno desenvolvimento de sua pessoa, preparo para o exercício da cidadania e qualificação para o trabalho (...).

A Lei de Diretrizes e Bases da Educação Nacional - LDB, Lei 9394/96 utiliza claramente no corpo de seu texto a palavra integral. Ao falar de conceitos da educação integral valoriza a participação da família e da comunidade nos processos educativos, buscando o desenvolvimento integral da criança e prevê o aumento gradual da jornada escolar para o ensino fundamental, buscando assim a educação integral. Os artigos 29 e 34 da LDB tratam desse assunto da seguinte forma:

Art. 29. A educação infantil, primeira etapa da educação básica, tem como finalidade o desenvolvimento integral da criança até seis anos de idade, em seus aspectos físico, psicológico, intelectual e social, complementando a ação da família e da comunidade.

Art. 34. A jornada escolar no ensino fundamental incluirá pelo menos quatro horas de trabalho efetivo em sala de aula, sendo progressivamente ampliado o período de permanência na escola.

$\S 1^{\circ}$ São ressalvados os casos do ensino noturno e das formas alternativas de organização autorizadas nesta Lei.

$\S 2^{\circ} \mathrm{O}$ ensino fundamental será ministrado progressivamente em tempo integral, a critério dos sistemas de ensino.

O Plano Nacional da Educação - PNE traz uma preocupação com as crianças das camadas sociais mais necessitadas, por isso defende o ensino integral prioritariamente a 
esta camada da sociedade. O PNE, levando em consideração a situação sócio-econômica brasileira, propõe que o ensino integral seja oferecido principalmente às crianças de idades menores, com famílias de renda mais baixa, com os pais trabalham fora de casa.

O PNE enfatiza que inteligência não é uma característica nata herdada dos seres humanos, mas sim um conjunto de habilidades que são adquiridas ao longo dos anos de estudo e de interação entre os indivíduos, devido a isso o PNE defende uma educação integral de qualidade a partir da educação infantil, uma vez que esta é o início de desenvolvimento da criança ao ingressar na escola. O Plano Nacional da Educação da mesma forma que a LDB propõe o aumento gradativo da jornada escolar até a implantação da educação integral em si, mas observa que esse processo deve se dá através de uma educação de qualidade e completa para que se eleve a escolarização da população brasileira. Conforme artigos 21 e 22 do PNE:

21. Ampliar, progressivamente a jornada escolar visando expandir a escola de tempo integral, que abranja um período de pelo menos sete horas diárias, com previsão de professores e funcionários em número suficiente.

22. Prover, nas escolas de tempo integral, preferencialmente para as crianças das famílias de menor renda, no mínimo duas refeições, apoio às tarefas escolares, a prática de esportes e atividades artísticas, nos moldes do Programa de Renda Mínima Associado a Ações Sócioeducativas.

O Fundo Nacional de Manutenção e Desenvolvimento do Ensino Fundamental e Valorização do Magistério - FUNDEB, regido pela lei 11.494/2007 trata da distribuição de recursos para a educação e dá prioridade às matrículas de tempo integral entendida como aquelas de duração igual ou superior a sete horas diárias. O FUNDEB faz referência a LDB que há mais de uma década propunha a implantação da educação integral, bem como o Decreto no 7083 de 27 de janeiro de 2010 que dispõe sobre o Programa Mais Educação, projeto responsável por nortear a educação integral brasileira, que foi criado com base no artigo 34 da LDB que prevê a ampliação da jornada escolar e nas leis $n^{\circ}$ 10.172/2001 (Plano Nacional de Educação) e no 11.947/2009 (sobre o atendimento da alimentação escolar e do Programa Dinheiro Direto na Escola aos alunos da educação básica). 


\subsection{CONDICIONALIDADES DO PROGRAMA}

Aqui iremos compreender um pouco como funciona a jornada ampliada e o que é necessário para que a mesma aconteça. Na implantação da Educação Integral há a necessidade de espaço físico adequado, pessoal suficiente, como professores e servidores bem como recurso financeiro capaz de arcar com as despesas da escola.

A escola de educação integral, segundo Gadotti (2009), deve levar em consideração cinco objetivos importantes, a saber: a escola integral deve educar para e pela cidadania, deve criar hábitos de estudo e pesquisa, deve cultivar hábitos alimentares saudáveis e de higiene, deve suprir a falta de opções oferecidas pelos pais ou familiares e deve ampliar a aprendizagem dos alunos além do tempo em sala de aula. Isso quer dizer que a educação integral tem necessariamente que complementar a educação com atividades extras que englobem esportes, cultura, lazer, línguas estrangeiras, cuidados com a saúde, estudos sociais, teatro, música, canto, informática, artes plásticas, artesanato e demais atividades que busquem o desenvolvimento humano com ênfase na dimensão cognitiva e afetiva de cada aluno.

A metodologia da educação integral tem a função de melhorar e auxiliar a aprendizagem dos alunos e isso tem que acontecer com o apoio da família e da comunidade. Com isso, a escola integral visa um desenvolvimento completo de qualidade que promova a integração da cultura com as ciências. Não se trata apenas de estar na escola em tempo integral, mas sim desenvolver todas as potencialidades humanas.

A escola integral de qualidade tem que unir educação de qualidade com cultura, saúde, transporte, assistência social com isso busca-se desenvolver todas as potencialidades humanas, que envolvem o corpo, a mente, a sociabilidade, a arte, a cultura, a dança, o esporte, o lazer.

Na educação integral não é suficiente estender o horário das aulas para 7 ou 8 horas

diárias. É preciso que o currículo seja integrado e que as disciplinas conversem entre si. Com isso, o aluno aprende as matérias de forma integrada e não separada como costumamos ver, além de que também o aluno tem contato com várias áreas de conhecimento. 
Para um bom funcionamento desse programa é imprescindível que a família seja ator nesse cenário também. Entenderemos a seguir o papel e a importância que a família exerce no bom funcionamento desse processo educativo.

\subsection{EDUCAÇÃO INTEGRAL E FAMÍLIA}

A família é peça chave para um bom desempenho dos resultados de educação integral, conforme dito. Os pais devem ser participativos e presentes no cotidiano e na vida escolar de seus filhos. Da mesma forma, a escola deve estar aberta a essa interação. A escola deve ser capaz de saber valorizar o que cada aluno traz de conhecimento consigo, o que aprendeu em casa com a família, uma vez que a educação familiar é a primeira no processo educativo.

A escola precisa valorizar os ensinamentos antigos, as tradições, os costumes, enfim

a cultura de cada um. É preciso incorporar a educação formal, a informal e não-formal. Todas elas contribuem para o aprendizado de cada indivíduo e grande parte do conhecimento que as crianças têm é herdado da família.

O conhecimento que a criança leva para a escola é dependente do grau de envolvimento da família no que tange à formação cultural. A criança no seio familiar tem acesso à cultura de acordo com as especificidades e possibilidades de cada grupo familiar. Então o que ela sabe vai depender do quanto sua família a expôs ao conhecimento.

É importante também observar que não só a família, mas também a comunidade deve ser responsável e participante desta educação. É necessário haver integração entre a cidade e a escola, é o que (Moll, 2000), chama de cidade educadora. O município também é um ente participante do processo educativo e também educa e ao mesmo tempo esse processo possibilita o desenvolvimento local da comunidade, uma vez que a educação integral visa integrar atividades sociais, econômicas, culturais, políticas e principalmente educativas.

A criança tem suas chances de aprenderem ampliadas quando seus pais atuam e participam da vida escolar de seus filhos, segundo (Gadotti, 2009), os pais nesse processo 
também aprendem. A educação integral deve fazer interagir escola e pais para que se tenha um bom resultado desse processo educativo. Além da participação dos pais, deve-se preocupar também com a inserção de políticas sociais em que venham agir em prol da escola e da comunidade.

\subsection{EDUCAÇÃO INTEGRAL E POLÍTICAS SOCIAIS}

Construir uma escola capaz de desfazer as diferenças e universalizar o acesso, a permanência e a aprendizagem da escola pública, é um dos objetivos da Educação Integral como política social, (Gadotti, 2009). As mudanças que se tem na atualidade, devido à globalização, as mudanças no trabalho, as transformações técnico-científicas tornam clara a necessidade de se investir e melhorar a educação pública. É muito comum ver alunos egressos de escolas públicas não terem as mesmas oportunidades que os que foram preparados em escolas particulares bem mais equipadas e completas que as públicas.

A Educação Integral visa diminuir essas desigualdades no acesso ao conhecimento e diminuir as disparidades na hora de se buscar um trabalho ou aprovação em vestibulares. Sabe-se que a situação de vulnerabilidade e desigualdade social contribuem, de certa forma, para um baixo rendimento escolar e consequentemente distorção idade/série e evasão escolar. A jornada ampliada ao oferecer oportunidades que a criança não teria faz com que ela se interesse e se mantenha na escola, evitando a evasão escolar. Sabe-se também que o direito a educação e, principalmente, uma educação de qualidade, além de direito público subjetivo este abre espaço para a conquista dos demais direitos até se concretizar na democracia em si.

A escola integral ao oferecer para seus alunos alimentação, saúde, higiene, atendimento médico-odontológico, transporte nos mostra que ela está presente e atuante nos campos de políticas sociais. Na verdade, a escola integral de hoje oferece bens e serviços que as crianças de baixa renda não têm acesso em suas casa devido às desigualdades sociais. Só que educação integral como política social não pode anular a função da escola de ensinar e entregar a ela as obrigações que cabe ao governo resolver. Mas ao mesmo 
tempo, percebe-se que as funções da escola foram ampliadas chegando a tratar de assuntos que são próprios da assistência social.

Entendemos nesse capítulo o conceito de Educação Integral, percebemos a existência da mesma desde a década de 40 no Brasil e também a sua autenticidade na nossa legislação. Foram apresentadas as condicionalidades do programa, a relação que a jornada ampliada tem com a família e o papel das políticas sociais nesse processo, conforme vimos. A partir de uma reflexão sobre a Educação Integral, iremos refletir como esse conjunto de idéias está operacionalizado na prática, em escola pública do Distrito Federal. 


\section{CAPÍTUlO 2 - A PRÁtica dA EdUCAÇÃo INTEGRAL NUMA ESCOLA PÚBlica dO DF: CAIC JUSCELINO KUBITSCHEK DE OLIVEIRA (CAIC - JKO) - NÚCLEO BANDEIRANTE - DF}

Vamos relatar a experiência concreta com a proposta da Educação Integral na escola pública do Distrito Federal que se situa no Núcleo Bandeirante, onde realizamos uma prática pedagógica por meio do Projeto $4 \mathrm{com}$ dois semestres, observando e refletindo sobre as condições reais em que a proposta da Educação Integral ocorreu, de modo que possamos refletir os desafios para implementação do programa nas escolas públicas do DF. Tais reflexões foram feitas a partir de uma observação ativa nas escolas, bem como entrevistas com os atores sociais diretamente envolvidos neste programa.

\subsection{BREVE HISTÓRIA DO NÚCLEO BANDEIRANTE}

Apresentaremos um breve relato do contexto geográfico onde a escola, objeto da pesquisa, está inserida para que possamos entender a importância da relação da escola com a comunidade. É feita também uma pequena passagem pela história do Núcleo Bandeirante, pela história do CAIC-JKO e, finalmente conheceremos a jornada ampliada na prática desta escola.

O Núcleo Bandeirante é uma cidade-satélite localizada a aproximadamente $15 \mathrm{~km}$ do centro de Brasília. Faz parte das cidades-satélites que compõe o Distrito Federal. Foi criada para servir de área comercial aos pioneiros de Brasília. Antigamente se denominava "cidade livre" (referência ao não pagamento de impostos pelos comerciantes, como estratégia de atraí-los para o local), vindo depois a adquirir sua atual denominação. Inicialmente a cidade tinha data para começar e terminar sua existência (1956/1960), período da construção da Capital Federal. Por isso, não havia planejamento de unidades fixas de residências. Os lotes ocupados deveriam ser devolvidos em 1959. As construções do Núcleo Bandeirante eram todas em madeira com cobertura de chapas de alumínio, zinco, ou mesmo palha. Sua população inicial era de 2212 pessoas, composta basicamente por homens, operários da construção civil. 
Com o passar dos anos sua população foi aumentando sistematicamente, devido às propagandas que se faziam na época da "Cidade Livre". Com excesso de pessoas vindas para cá, surgem moradias irregulares, comércio, pensões e multiplicam as invasões. Chegada à época da inauguração de Brasília, e conseqüentemente a desmontagem da cidade, os moradores se reúnem para reivindicar a fixação definitiva da mesma. Tal ação foi chamada de Movimento Pró-fixação e Urbanização do Núcleo Bandeirante - MPFUNB. Os moradores se juntaram nas diferentes categorias de trabalhadores que existiam na cidade, desde donas-de-casa até comerciantes e professores. O movimento montou estratégias para pressionar o governo local, como a criação de creches para abrigar as crianças, cursos de alfabetização, propaganda explícita, comícios, articulação com alguns parlamentares, dentre outros meios.

Os moradores conquistaram a vitória e a fixação definitiva do Núcleo Bandeirante ocorreu em 1961. A partir daí o MPFUNB passou a reivindicar infra-estrutura para a cidade. Vemos que o êxito do MPFUNB deu-se devido à organização da sociedade civil e os movimentos sociais, que lutaram em conjunto com vínculos cooperativos para a consolidação do Núcleo Bandeirante.

A população de pioneiros que aqui se formou é diversificada, oriunda de toda parte do Brasil. Isso gerou uma comunidade com interesses e habilidades diversas nos aspectos econômicos, político, social e cultural. Atualmente, a cidade é composta pelos seguintes setores: Núcleo Bandeirante tradicional, Vila Metropolitana, Vila Nova Divinéia, Setor de Mansões Park Way, Setor de Indústria Bernardo Sayão, Setor de Postos e Motéis (EPIA), Setor de Postos e Motéis Sul (EPNB), Setor Placa da Mercedes, Área de Desenvolvimento Econômico, Núcleo Rural Vargem Bonita, Córrego da Onça, Colônias Agrícolas NB1 e NB2, Coqueiros, Arniqueira (parte), Bernardo Sayão e recentemente Vila Cauhy. A população atual é de aproximadamente 36.400 habitantes.

Hoje o Núcleo Bandeirante tradicional e as Vilas Metropolitana e Nova Divinéia são responsável por elevar o padrão de vida do Núcleo Bandeirante, o padrão de vida desses habitantes é bastante elevado. Em contrapartida na Vila Cauhy situação é bem diferente. A Vila é formada principalmente por famílias carentes de baixa renda e baixa escolarização. É interessante também que na Vila Cauhy há moradores com alto poder aquisitivo, mas fazem parte de uma parcela mínima da população. 
A Vila Cauhy existe no Núcleo Bandeirante há mais de 40 anos, na verdade o local que ela ocupa hoje corresponde a um setor de chácaras com área equivalente a 1/4 do Núcleo Bandeirante. A Vila era um setor de chácaras predominantemente de plantio de hortaliças, com o passar dos anos a população foi aumentando e o espaço natural degradado. Atualmente se assemelha a um condomínio com vielas estreitas e aglomerado urbano intenso. A maior parte dos alunos que estudam no CAIC JKO provém da Vila Cauhy, de famílias de baixa renda e por vezes desestruturada. É comum notar situações em que a mãe sem companheiro sai para trabalhar e deixa os filhos pequenos sozinhos em casa, achando na educação integral sua opção segura.

Tal Vila é marcada pela violência, principalmente por causa do tráfico de drogas que existe o local e também é comum histórias de prostituição infantil e trabalho infantil na região. Talvez por sair para trabalhar o dia todo, os pais não têm controle sobre esses acontecimentos com seus filhos.

A Vila Cauhy não é uma região legalizada ocupa terreno irregular e aguarda sua legitimação como vila. O nome advém do Deputado Distrital Jorge Cauhy que muito fez pela vila e que faleceu há uns anos atrás. Hoje, a vila conta com uma praça criada pela Administração Regional do Núcleo Bandeirante, ganhou asfalto em pequenas áreas e também conta com um Ponto de Encontro da Comunidade onde existem equipamentos de ginástica que ficam ao lado do CAIC JKO.

As crianças da Vila Cauhy que estudam no CAIC têm o privilégio de ir para a escola com segurança, uma vez que a única pista que eles têm que atravessar possui uma faixa de pedestres que fica na lateral da escola.

Em conversa com a coordenadora do Núcleo de Planejamento e Controle, Luzinete Assencio, da Diretoria Regional de Ensino do Núcleo Bandeirante foi possível constatar algumas peculiaridades de suas escolas, como, por exemplo, a escola da Vila Metropolitana que tem parte de sua estrutura física de madeira, por ser Patrimônio da Humanidade e ter seu tombamento.

O Núcleo Bandeirante possui 11 escolas, a saber: Centro de Educação Infantil, Escola Classe 3, Escola Classe 4, Escola Classe 5, Caic Juscelino Kubitschek de Oliveira, Centro de Ensino Fundamental da Metropolitana, Centro de Ensino Fundamental da Vargem Bonita, Escola Classe Jardim Botânico, Escola Classe Ipê, Centro de Ensino 
Fundamental 1 do Núcleo Bandeirante e Centro de Ensino Médio 1 do Núcleo Bandeirante. As escolas classe 3 e 4 se destacam com um trabalho bem desenvolvido para educandos portadores de necessidades especiais, a Escola Classe Ipê tem as características de uma escola rural, pois é localizada num setor de chácaras chamado Granja do Ipê.

As escolas desta localidade não utilizam o Programa Mais Educação, isto quer dizer que o Índice de Desenvolvimento da Educação Básica (IDEB) destas escolas não é baixo de acordo com classificação do próprio índice. Uma outra característica importante é que estas escolas procuram ter um desenvolvimento uniforme e funcionam sincronizadas, isso quer dizer que não se pode dizer que uma escola é melhor do que outra, ou que uma possui mais recursos do que as outras. Não foi possível, para a coordenadora Luzinete falar qual escola se destaca mais, uma vez que ela nos disse que todas estão no mesmo patamar.

Conforme dito já em alguma parte deste trabalho os alunos destas escolas não necessariamente moram todos ou quase todos no Núcleo Bandeirante. Grande parte desses alunos são de outras localidades próximas ali dessa Região Administrativa, como é o caso da Escola Classe 5 que tem a maioria de seus alunos moradores da região Veredão localizada próximo a Cidade Satélite Riacho Fundo I.

A educação do Núcleo Bandeirante enfrenta problemas comuns da educação nacional; como a falta de dinheiro para desenvolver programas e projetos; excesso de alunos por escola; infra-estrutura precária; falta de pessoal, principalmente professores; e também a ausência dos pais nos destinos da escola. Um problema que não pode ser percebido, conforme entrevista e pesquisa em jornais, é a questão da violência nas escolas, não é que não exista, mas no Núcleo Bandeirante isso ocorre de uma forma reduzida.

Abaixo podem ser vistas algumas fotos via satélite do Núcleo Bandeirante, da Vila Cauhy e do CAIC Juscelino Kubitschek de Oliveira. 


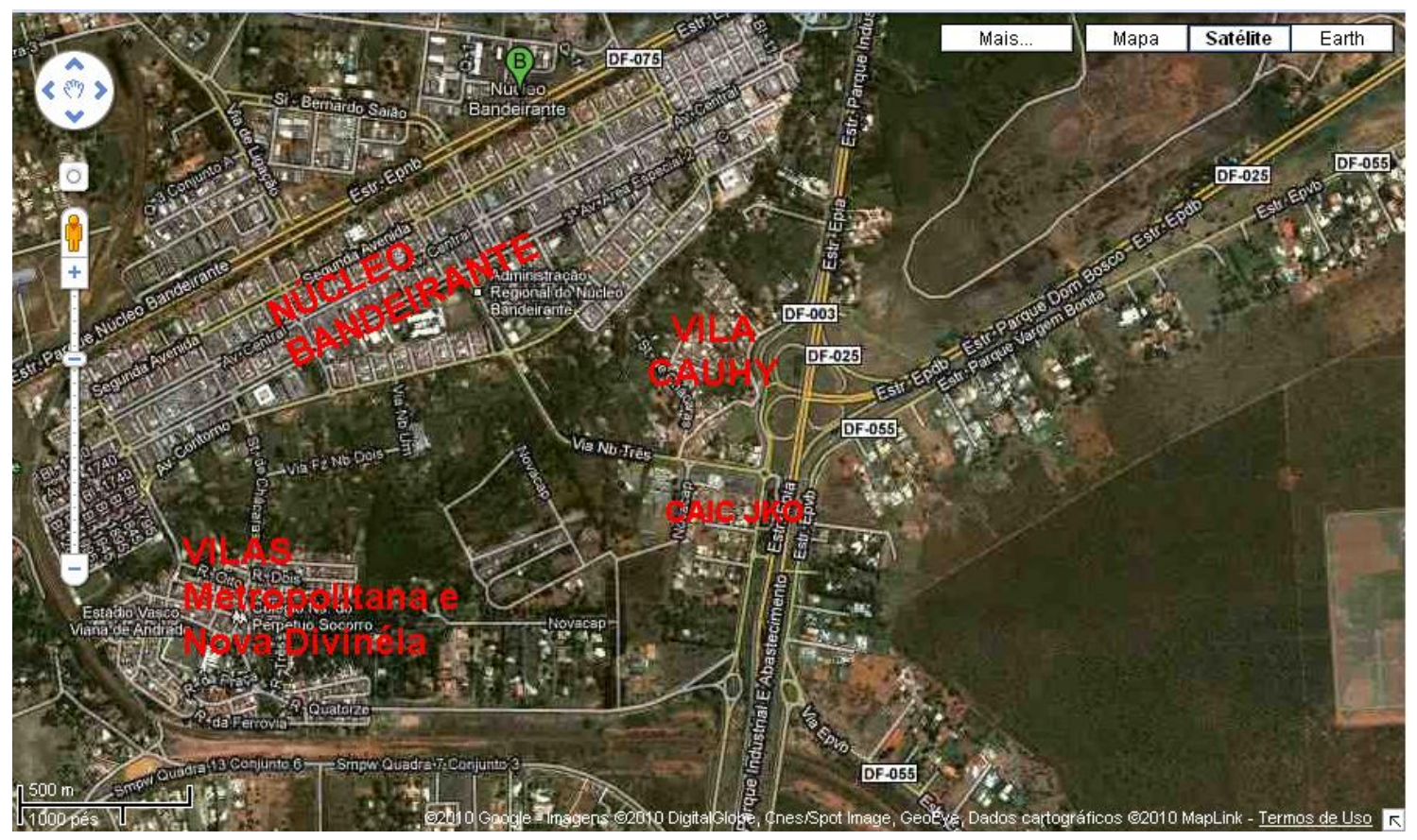

FOTO 1: Localização do Núcleo Bandeirante em relação à Vila Cauhy e ao CAICJKO.

A escolha da escola como objeto de estudo neste trabalho se deu por diversas razões. O principal motivo é a proximidade da escola à minha casa, na época da realização do Projeto IV tive que fazer visitas ao CAIC para conhecimento e análise do projeto e ficaria mais simples que fosse próximo para mim. Outra razão é a de ter visto o CAIC ser construído à época da implantação dos mesmos e, por isso ter a curiosidade de conhecer melhor a escola, também destaco a facilidade para conversar com os pais devido aos mesmos em grande parte serem meus próprio vizinhos. 


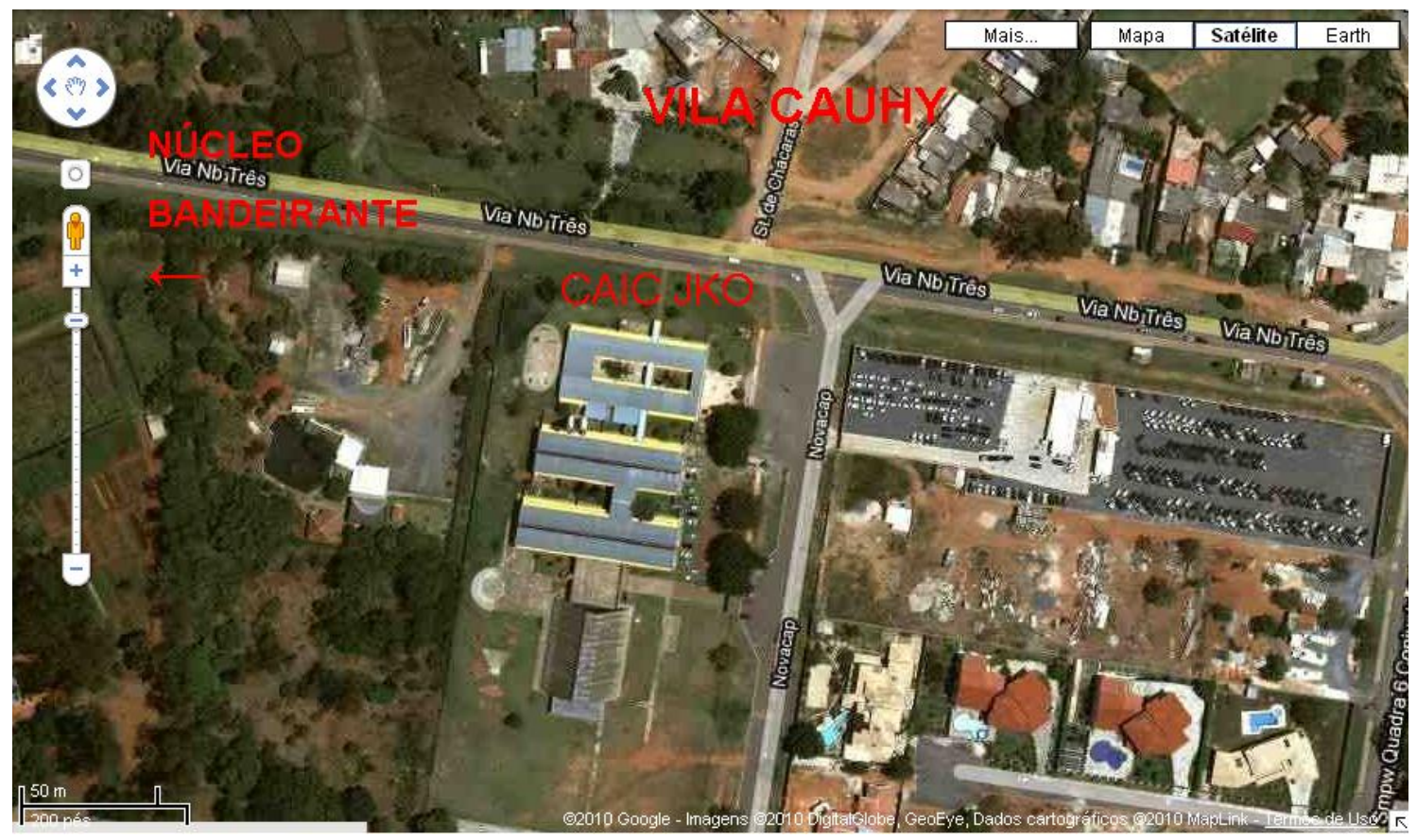

FOTO 2: Vista geral do CAIC - JKO

\subsection{HISTÓRIA E CARACTERÍSTICAS DO CAIC - JKO}

O Centro de Atendimento Integral à Criança Juscelino Kubitschek de Oliveira foi inaugurado oficialmente em 12 de março de 1993. Os CAIC's fazem parte de um projeto que é resultado do Encontro Mundial de Cúpula pela Criança, realizado em setembro de 1990 na sede das Nações Unidas, o Brasil foi signatário da "Declaração Mundial sobre a Sobrevivência, a Proteção e o desenvolvimento da Criança” e do corrente Plano de Ação para sua adoção. Nesse encontro foi criado o Programa Nacional de Atenção Integral à Criança e ao Adolescente no intuito de solucionar o grave problema social que atinge grande parte das crianças e adolescentes brasileiros, principalmente da Região Nordeste.

As obras dos CAIC's foram iniciadas no governo do Presidente Fernando Collor de Melo sendo finalizadas no governo de Itamar Franco. O CAIC JKO ocupa uma área de 3.700 metros quadrados, possuindo estrutura com 51 dependências (fotos 3, 4 e 5). Oferece várias modalidades de ensino e funciona apenas no turno matutino ficando o vespertino para as atividades de educação integral. Pela manhã é oferecido Educação Precoce, Educação Especial, Educação Infantil, Ensino Fundamental de 8 anos séries iniciais e finais 
( $3^{\mathrm{a}}$ à $8^{\mathrm{a}}$ série), Ensino Fundamental de 9 anos $\left(1^{\circ}, 2^{\circ}\right.$ e $3^{\circ}$ ano) e o Programa Escola Modelo de Educação Integral que atende turmas de $1^{\mathrm{o}}$ ano, $2^{\mathrm{o}}$ ano, $3^{\mathrm{a}}$ série e $4^{\mathrm{a}}$ série. $\mathrm{O}$ turno matutino funciona de $07 \mathrm{~h} 30 \mathrm{~h}$ às $12 \mathrm{~h} 30 \mathrm{~h}$ e o vespertino de $14 \mathrm{~h} 00 \mathrm{~h}$ às $16 \mathrm{~h} 00 \mathrm{~h}$.

O CAIC JKO tem alunos predominantemente de classe média baixa, com famílias em que pais e mães trabalham fora, grande parte deles trabalham no comércio ou vivem da agricultura. A escola é situada próximo à Vila Cauhy sendo rodeado pelo Núcleo Bandeirante e pelas Vilas Metropolitana e Nova Divinéia. Veja as fotos 3 e 4:

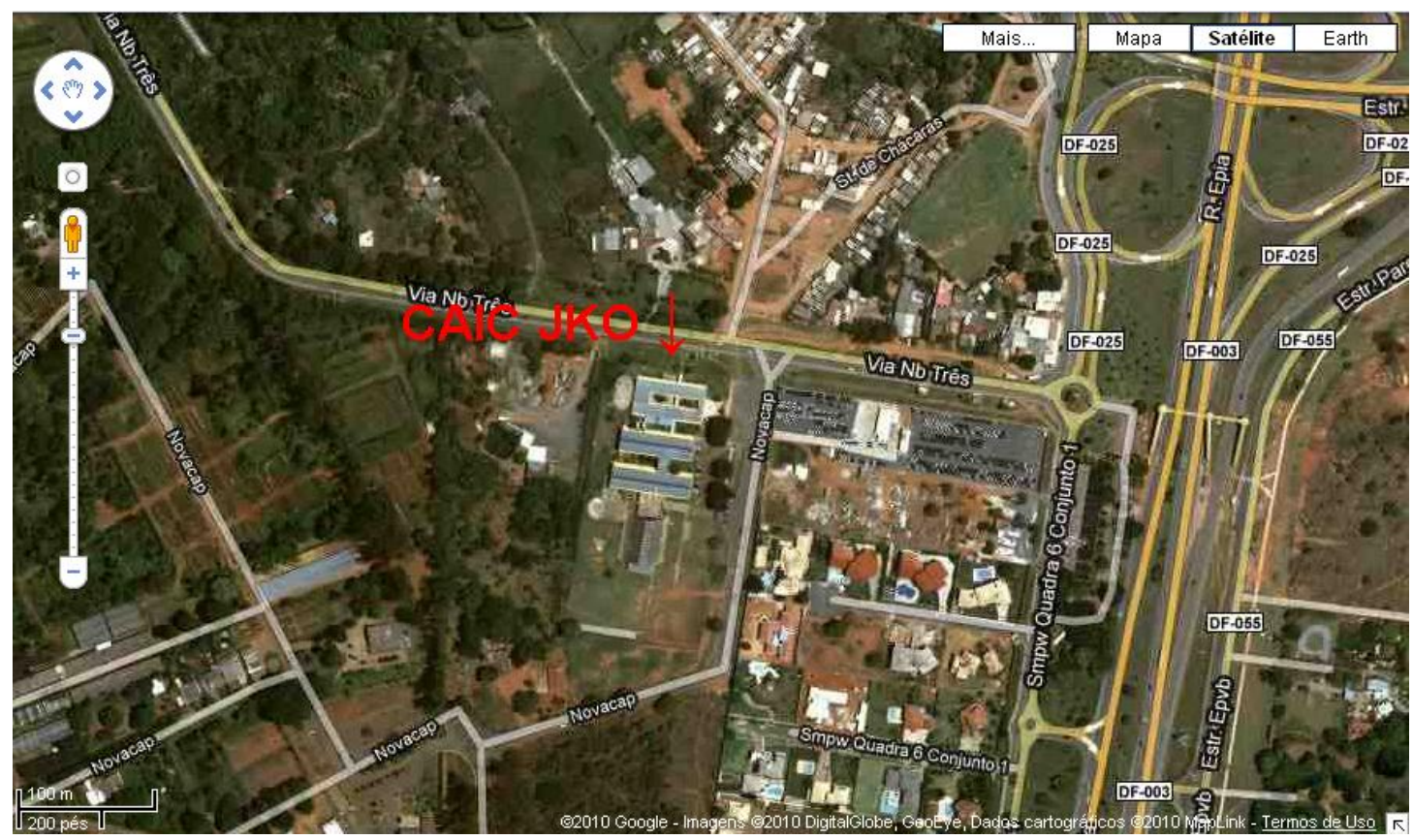

FOTO 3: O CAIC-JKO e sua localização geral. 


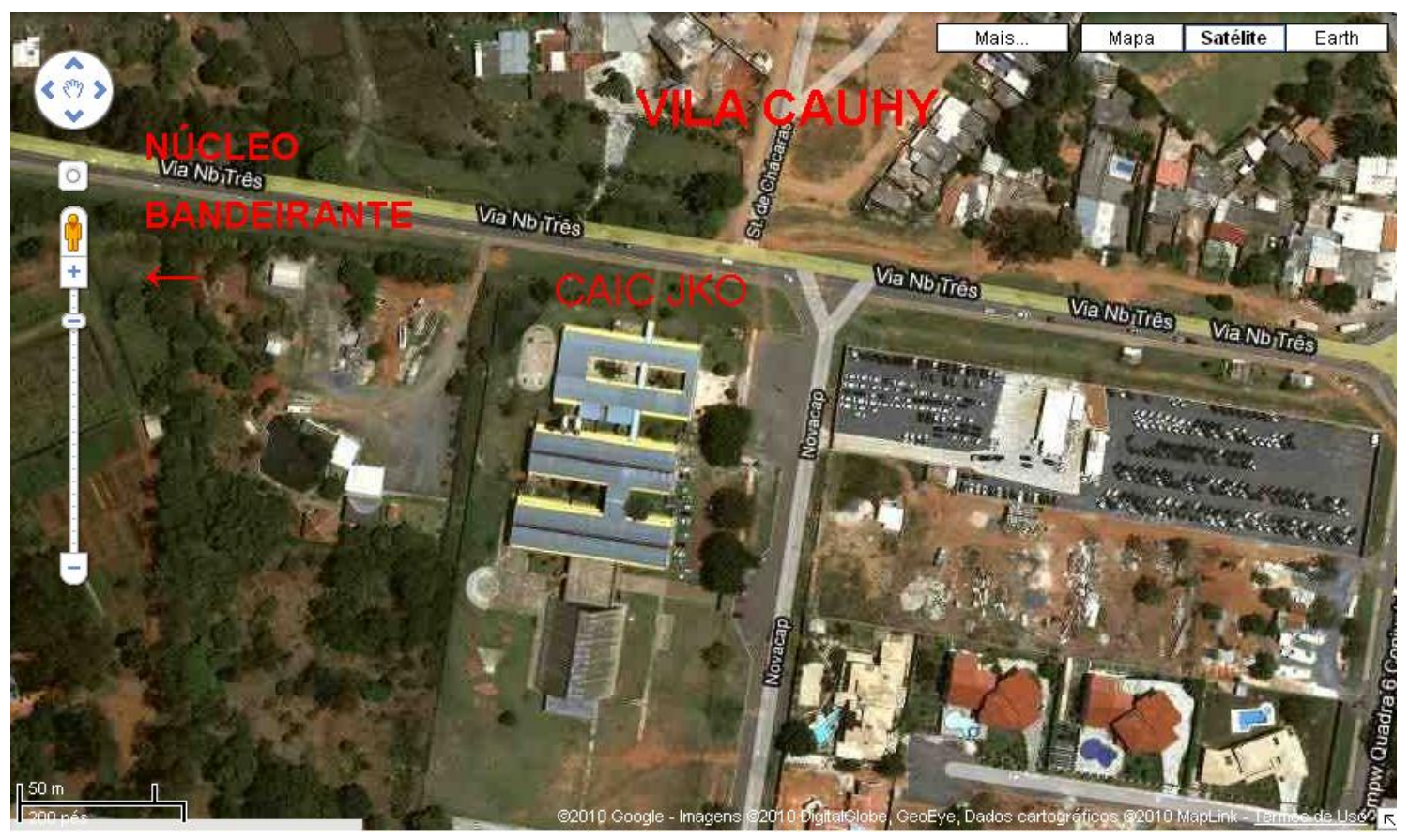

FOTO 4: Vista do CAIC-JKO com ênfase da proximidade da Vila Cauhy à escola.

O CAIC Juscelino Kubitschek de Oliveira tem cerca de 580 alunos, 55 professores, 27 turmas, sendo: 02 de Educação Precoce; 04 de Educação Especial, 2 de Educação Infantil; 03 de $1^{\circ}$ ano; 02 de $2^{\circ}$ ano; 03 de $3^{\circ}$ ano; 02 de $4^{\circ}$ ano $/ 3^{\mathrm{a}}$ série; 02 de $5^{\circ}$ ano $/ 4^{\circ}$ série; 02 de $6^{\circ}$ ano $/ 5^{\mathrm{a}}$ série; 02 de $7^{\circ}$ ano $/ 6^{\mathrm{a}}$ série; 01 de $8^{\circ}$ ano $/ 7^{\mathrm{a}}$ série; 01 de $9^{\mathrm{o}}$ ano $/ 8^{\mathrm{a}}$ série; 01 de Correção de Fluxo séries/anos iniciais. A estrutura física da escola é dividida da seguinte forma:

Prédio A - Educação Infantil: 4 salas de aula com 2 sanitários, 2 pias e 2 chuveiros; 7 salas de aula Adaptadas, sendo uma com um banheiro; 1 Sala de professores e coordenação da Estimulação Precoce; 1 Depósito; 1 sala da equipe de apoio a aprendizagem; 1 sala do SOE (Serviço de Orientação Educacional); 1 sala de Recursos; 1 banheiro para funcionários com dois sanitários e um chuveiro; 2 banheiros com um sanitário e uma pia cada, para alunos; 1 Playground com parque de areia; 1 Playground com parque.

Prédio B - Andar Superior, Ala I: 2 salas para sala de recursos; 1 sala para SOE; 1 auditório; 1 sala do SOE da DRE; 1 sala da supervisão pedagógica; 1 sala de fantasias; 2 
banheiros (masculino e feminino); 1 sala de depósito e 5 salas de aula para a escola modelo de educação integral.

Prédio B - Andar Superior, Ala II: 13 salas de aula; 2 banheiros (masculino e feminino).

Prédio C - Térreo: 1 Secretaria Escolar; 1 Mecanografia; 1 sala da TV Guri, 1 Consultório Dentário; 1 sala de descanso para Assistentes de Educação com um banheiro; 4 banheiros para funcionários; 2 vestiários para alunos (masculino e feminino); 1 sala da vice-direção; 1 sala da Direção com banheiro; 1 sala da Supervisão Administrativa; 1 sala da Supervisão Pedagógica; 1 Brinquedoteca; 1 Depósito Pedagógico; 1 Depósito de Material de Limpeza; 1 Depósito de Mobiliários escolar; 1 Almoxarifado; 1 Laboratório de Informática com banheiro; 1 sala para os vigilantes; 1 sala de aula; 1 sala para as aulas de judô e 1 sala de recursos.

Espaço Externo: 1 pátio coberto; 1 anfiteatro; 1 ginásio coberto; 1 playground; 2 vestiários (masculino e feminino); 1 campo de futebol gramado; 2 salas de depósito; 1 praça cívica; 1 estacionamento privativo e área verde. Veja foto 5 e a divisão dos prédios:

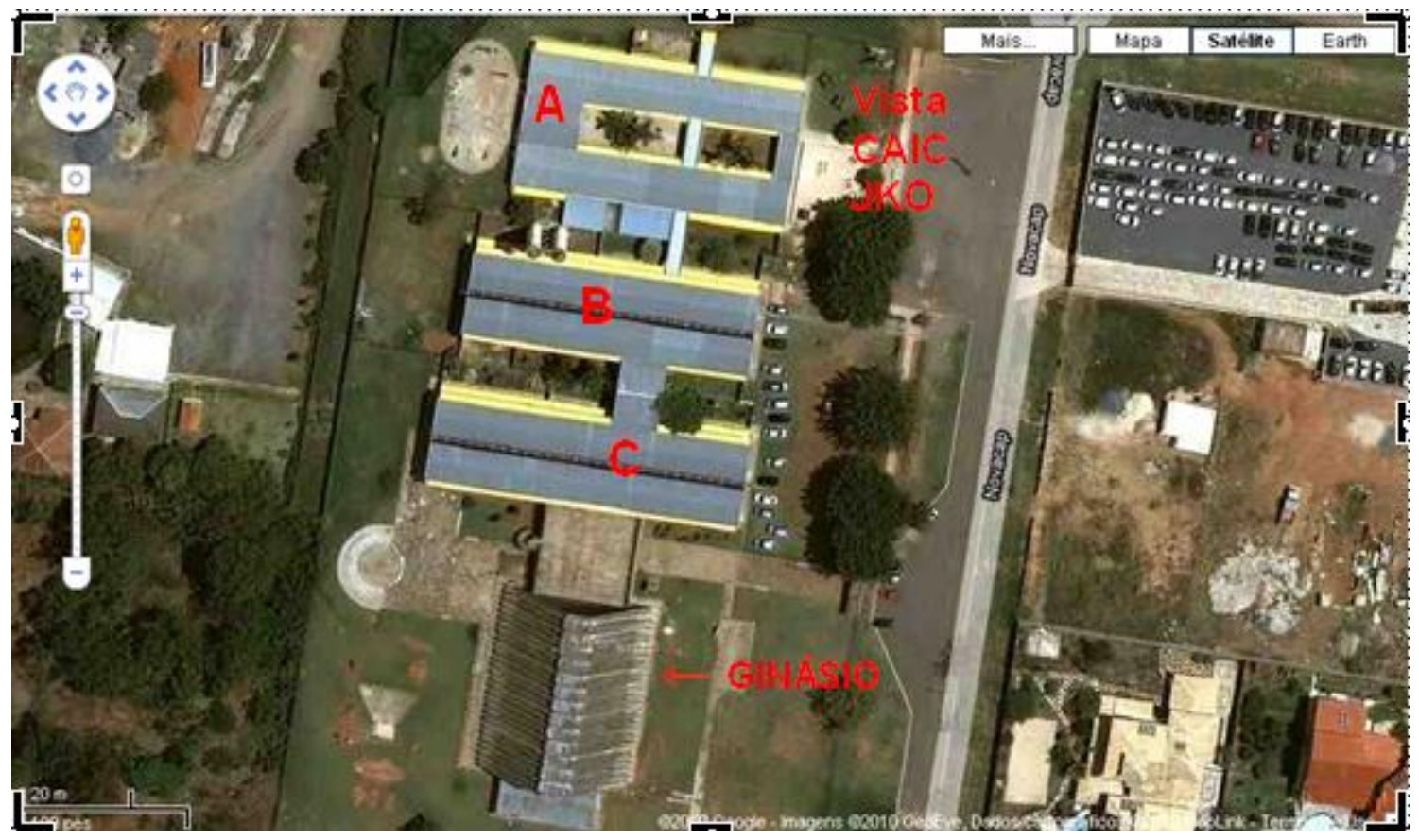

FOTO 5: Prédios do CAIC-JKO. 


\subsection{PROPOSTA DE INSERÇÃO DO PROGRAMA NA ESCOLA}

A Educação Integral do CAIC-JKO atende a 150 alunos do $1^{\circ}$ ao $5^{\circ}$ ano e 40 alunos de $5^{\mathrm{a}}$ a $8^{\mathrm{a}}$ série. O Programa é coordenado por uma professora e desenvolve no contra turno atividades de Judô com um professor da escola e com um pai de aluno que é voluntário e também artesanato com uma mãe de aluno que é voluntária. Conta com 4 monitores bolsistas. Tem oficina de jogos, como xadrez e outros jogos de tabuleiro, brincadeiras lúdico-esportivas, acompanhamento das tarefas de casa, acompanhamento do processo de alfabetização para os alunos do BIA (classes de alfabetização), incentivo a leitura, hora do conto e aulas de informática. Os alunos entram as 7:30 para as aulas do turno matutino, lancham, almoçam, descansam e após as oficinas lancham e vão embora as 16 horas. São oito horas e meia na escola durante quatro dias da semana.

A escola pretende incluir na grade capoeira, música e desenho, mas ainda não conseguiram nenhum parceiro voluntário para coordenar estas oficinas. A professora de Educação Física, além de lecionar pela manhã, coordena e supervisiona o projeto de basquete e implantará aulas de vôlei.

A escola não recebe nenhum recurso financeiro para desenvolvimento do projeto, todo custeio tem que partir da contribuição dos pais pela APM, doações, sorteios, bazares e até mesmo rateio entre os profissionais que atuam no programa de Educação Integral e a direção da escola.

O Programa funciona desde 2008 e muitos pais precisam deixar os filhos na escola integral para poder trabalhar fora. O Projeto não é oferecido a todos os alunos porque a escola apesar de ter espaço e ser estruturada para isso, não tem recursos materiais e nem pessoal suficientes. A educação integral da escola é um projeto em fase de teste, anteriormente quando era o Programa Escola Modelo de Educação Integral era muito burocratizado e complexo. Hoje, o projeto é de responsabilidade da escola e bem mais simples de ser posto em prática.

O horário que a escola atende as crianças da educação integral é de 7:30 às 16:00. No turno da manhã as crianças têm as disciplinas tradicionais oferecidas pela escola, a saber: português, matemática, estudos sociais e ciências. O período de almoço e descanso e 
de 12:30 às 14:00, retornando às 14 horas para a realização das atividades extracurriculares no turno da tarde. De acordo com a pesquisa do MEC, Educação integral/educação integrada e(m) tempo integral: concepções e práticas na educação brasileira, grande parte das escolas que têm a experiência de jornada ampliada, desenvolvem as atividades no turno contrário da mesma forma isso acontece no CAIC-JKO. A seguir veja fotos das atividades de basquete e xadrez na escola:

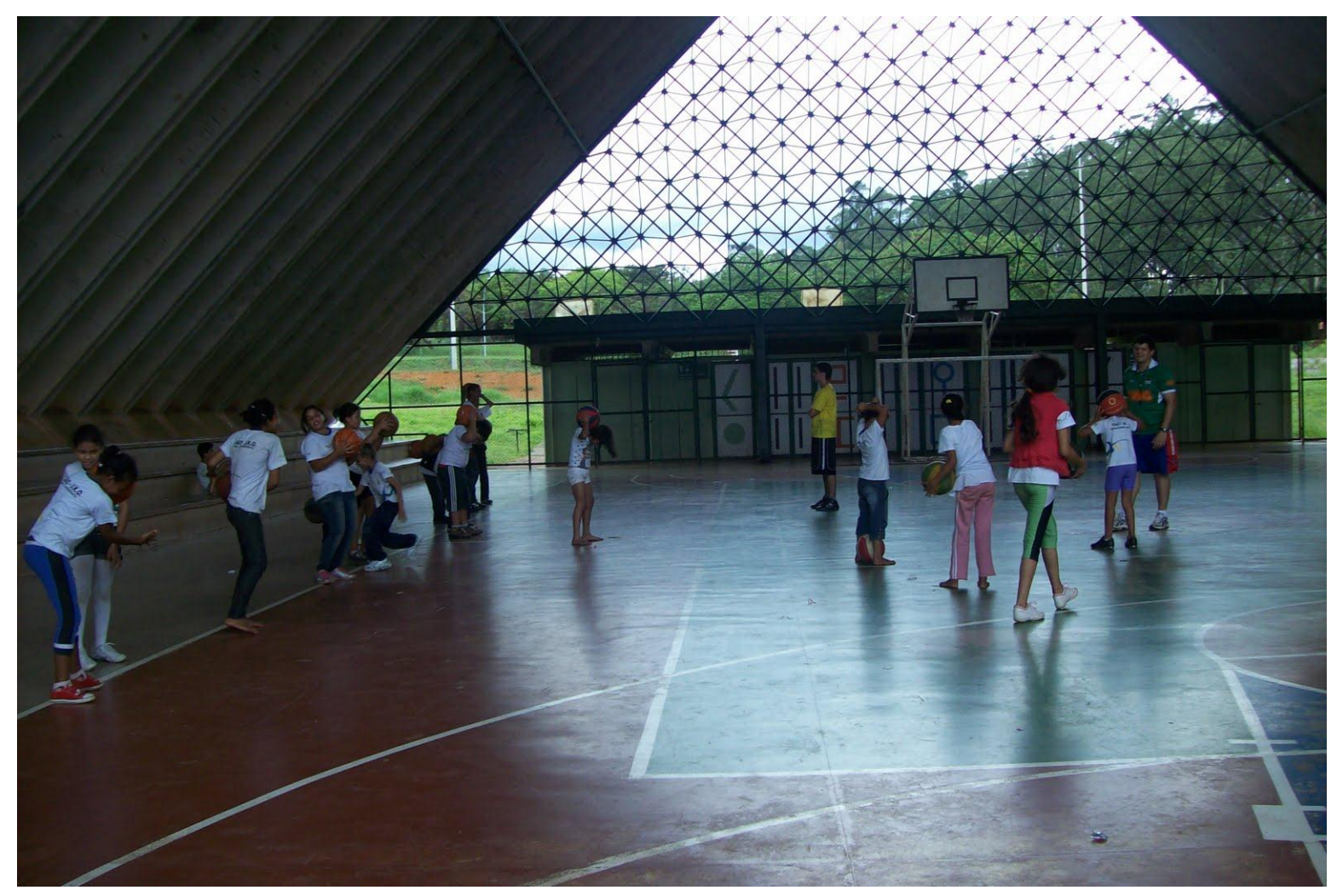

Foto 6: Aulas de basquete. 


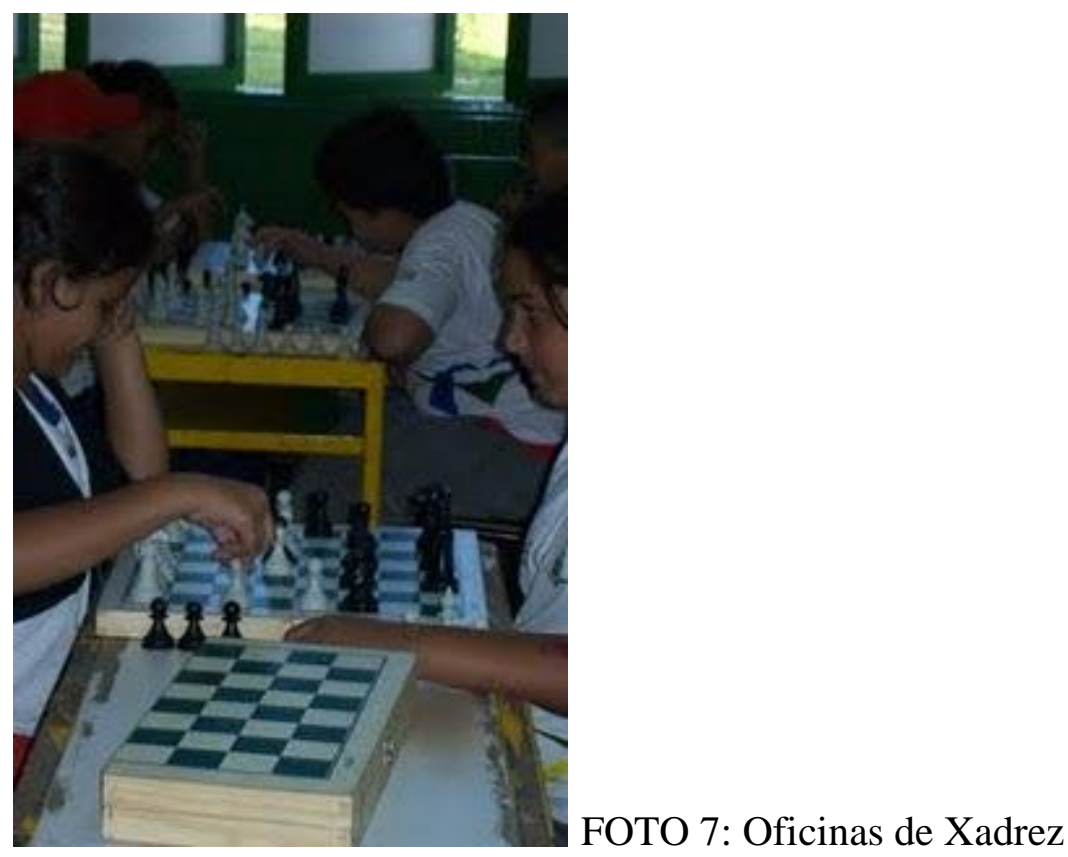

Ainda conforme esta pesquisa, constatou-se que as experiências de jornada ampliada no país têm sido recentes, ou seja, foram implantadas desde 2008 e que as atividades diárias duram em média 7 horas diárias com atividades nos cinco dias da semana. No CAIC-JKO, o projeto também é recente e ainda precisa de tempo para colher dados sobre o andamento do programa, têm carga horária em torno de 7 a 8 horas ao dia, se considerados os períodos de lanche, almoço e descanso. Mas, as aulas funcionam apenas quatro dias na semana, ou seja, de segunda a quinta-feira.

Pôde-se constatar também na pesquisa já citada, que as atividades dentro da escola geralmente ocorrem, preferencialmente, na sala de aula, no pátio da escola e na quadra de esportes. O CAIC utiliza esses mesmos espaços para suas oficinas, pela manhã as crianças estão nas salas de aula tendo aulas, à tarde utilizam também as salas para aulas de reforço, o pátio para aulas de dança, oficinas de artesanato e a quadra para a prática do basquete, por exemplo. O CAIC-JKO não têm utilizado muito espaços fora da escola, ao contrário das demais escolas brasileiras que realizam atividades em campos de futebol, praças públicas, quadras de esportes, bibliotecas, etc. No Núcleo Bandeirante, os alunos se restringem a passeios no Zoológico, ou no principal parque da cidade. Após conhecer a escola e sua estrutura falaremos sobre o Projeto Político Pedagógico da escola. 
A educação integral da escola é um projeto novo apesar da sua estrutura ter sido criada para isso. A escola não utiliza o Programa de Educação Integral Mais Educação porque não apresenta baixo Índice de Desenvolvimento da Educação Básica (IDEB) de acordo com exigências do próprio programa e, então condição necessário para adesão ao projeto.

Como se pode perceber, através do Projeto Político Pedagógico da escola em anexo no final deste trabalho, o CAIC não é uma escola exclusivamente de Educação Integral e em seu PPP fica claro que o CAIC-JKO tem outros projetos e outras prioridades. Conforme a pesquisa do MEC, Educação integral/educação integrada e(m) tempo integral: concepções e práticas na educação brasileira, a grande maioria das escolas de educação integral no Brasil tem a experiência integrada no PPP, e, com isso, da mesma forma o CAIC-JKO.

A proposta pedagógica conforme o PPP da escola visa: "valorizar o ser humano, objetivando seu desenvolvimento bio-psico-social e cultural, respeitando as diferenças pessoais e coletivas, proporcionando-lhe um processo de educação integral para agir criticamente na sociedade, instrumentalizando-o para vivenciar valores baseados na solidariedade, na austeridade, na cidadania, na colaboração e na responsabilidade, assim como, proporcionar uma educação de qualidade que garanta uma aprendizagem significativa do aluno e diminua, progressivamente, a retenção e a evasão escolar” (PPP CAIC JKO, 2010, p.102 e 103). Na prática, busca-se cultivar hábitos alimentares saudáveis, a socialização, a prática de esportes, o lúdico, as atividades em equipe, a distração, as artes e o artesanato, a música dentre outros. Para isso os alunos têm oficinas de capoeira, futsal, dança, poesia, artes plásticas, coral, aulas de instrumentos musicais, acompanhamento pedagógico e informática.

\subsection{REFLEXÕES DO RESULTADO DA PESQUISA NA ESCOLA SOBRE EDUCAÇÃO INTEGRAL}

A coleta de dados para entender a educação integral do CAIC-JKO ocorreu através de várias visitas à escola. Foram feitas entrevistas através de gravação de voz, entrevistas com conversas informais e também a aplicação de questionários com alunos e pais como podermos ver no tópico seguinte. 
Em entrevista com a coordenadora de educação integral pode-se perceber que a escola enfrenta diversas dificuldades para por em prática o projeto de educação integral. $\mathrm{O}$ motivo principal desses problemas é que o CAIC-JKO não recebe do governo dinheiro exclusivo para ser utilizado pela educação integral. Na verdade, o repasse do governo é direcionado para escola como um todo e cabe à direção destinar os recursos necessários para a educação integral. Como a verba não é suficiente, o projeto passa por diversas dificuldades, como a falta de dinheiro para comprar o gás para fazer almoço para as crianças.

Muitos dos materiais utilizados nas atividades são comprados, segundo a Professora, pelos próprios professores e funcionários da escola. Quando precisam de um material urgente para executar determinado trabalho os professores arrecadam dinheiro dos seus colegas de trabalho ou fazem bazares para compra dos materiais. Com isso, a escola vem enfrentando muitos problemas financeiros.

Outro problema recorrente é o fato de não ter pessoal suficiente para ministrar determinadas oficinas. As atividades no período vespertino são oferecidas por monitores e não por professores - há apenas dois professores da educação integral - uma Professora que dá aulas de reforço das disciplinas aprendidas de manhã (português, matemática, ciências, estudos sociais e artes) e um Professor, como dito anteriormente, que dá aulas de educação física e atualmente oferece aulas de judô no turno da tarde.

Tais monitores são oferecidos através de contrapartida do governo do Distrito Federal em pagar parte das faculdades dos mesmos ao passo que estes tem de prestar serviços gratuitos ao GDF num total de 4 horas semanais, tais serviços se dão em diversos cenários desde escolas à repartições públicas. Por isso, não há monitor suficiente e muitos deles faltam às atividades por diversos motivos. Há também monitores voluntários, que já é mais difícil encontrar na escola, uma vez que os poucos que tinha desanimaram pela distância de suas residências e falta de recursos próprios para irem até a escola, além de que a falta de materiais dificultava o trabalho dos mesmos.

É interessante notar que, na pesquisa citada anteriormente, as aulas e as oficinas da educação integral, em grande parte, são ministradas por professor concursado e professor contratado, o que ocorre de forma diversa do CAIC, que tem a maior parte das oficinas sob regência de monitores. Nessas escolas, geralmente o responsável específico pela 
experiência são os diretores da escola e quem coordena é a Secretaria de Educação de cada Estado, e já no CAIC-JKO, tem-se um coordenador específico só da Educação Integral e a coordenação geral cabe à própria diretora da escola.

\subsection{A PERCEPÇÃO DOS PAIS E ALUNOS SOBRE EDUCAÇÃO INTEGRAL E RESULTADOS DAS OBSERVAÇÕES FEITAS NA ESCOLA}

Através da entrevista feita com pais e alunos envolvidos na educação integral, para conhecer a compreensão que os mesmos têm de jornada ampliada foi possível conhecer um pouco do pensamento deles sobre o tema. Devido a dificuldades de encontrar os pais na escola e também pelo fato de a maioria trabalhar fora, foram entrevistados com questionários 10 mães de alunos matriculados na Educação Integral e cerca de 15 crianças, também foi feita uma roda de conversa com as crianças em uma das observações em sala. É interessante observar que ambos têm a mesma noção do conceito e da importância desta modalidade. A princípio será abordada a opinião dos pais e posteriormente a dos alunos.

A maior parte das mães entrevistadas mora na Vila Cauhy, seguido de Núcleo Bandeirante e Park Way. Geralmente são mães solteiras que trabalham em atividades demésticas ou no comércio e têm em média 2 filhos. A renda familiar gira em torno de um salário mínimo e grande parte delas recebe auxílio do governo para manterem os filhos na escola.

Essas mães entendem educação integral como algo relacionado a tempo. Para elas escola integral é aquela em a criança fica mais tempo em aula do que o comum (um turno apenas). A maioria delas matriculou seu filho na jornada ampliada porque não tem com quem deixar os filhos para trabalhar, como dito são mães solteiras, ou divorciadas, que não tem companheiro e nem a ajuda financeira deles para poder arcar com uma creche ou remunerar alguém para cuidar de seus filhos.

A escola aqui passa a ter um papel assistencialista, pois cuida das crianças para os pais poderem trabalhar fora. Outro aspecto relevante é a questão da alimentação, muitos

pais matriculam os filhos para que possam ter uma alimentação saudável e balanceada, já 
que grande parte das famílias dos alunos matriculados é de baixo poder aquisitivo e também não têm conhecimentos sobre alimentação saudável.

As mães sabem que estando matriculados na educação integral, seus filhos ficam mais tempo longe da rua e têm a oportunidade de aprender mais, sabem que estão na escola seguros, como pensam a maioria. É relevante o acesso que os alunos têm a culturas que eles não poderiam conhecer se não estivessem lá, como por exemplo, aprender a jogar xadrez, aprender a manusear um computador, aprender a lutar judô, dentre outras atividades.

No geral, as mães não têm tempo de participar da vida escolar de seus filhos, pois geralmente as reuniões da escola acontecem durante a semana período em que os mesmas estão no trabalho. Mas, destaca-se também a própria falta de interesse delas sobre as notas dos alunos, na participação de eventos da escola, e também o desinteresse sobre os deveres de casa, mas sabemos que isso é motivado por questões sociais históricas que não cabe esta discussão nesta monografia. Muitos pais só aparecem na escola quando seus filhos estão correndo riscos de serem desligados do projeto, é o que comentou a coordenadora do projeto de Educação Integral da Escola, em entrevista.

As mães entrevistadas acham que o projeto deveria ser estendido a toda a escola, mas reconhecem que o CAIC-JKO enfrenta dificuldades financeiras para pôr em prática a jornada ampliada. Consideram também que as aulas deveriam ser até às 18 horas e não só até às 16:00 como é feito. Às vezes as crianças têm que voltar para suas casas sozinhas, pois não tem ninguém para buscá-las ou então, geralmente voltam para casa em grupos para não ser perigoso. Elas acham também que poderiam ter campanhas de saúde que funcionassem de verdade, a escola tem um consultório odontológico e nunca funciona por não ter dentista. Os alunos também poderiam ter como fazer o exame de vista e demais exames médicos necessários. Enfim, o projeto deveria realmente ter a função social para o qual foi criado.

Falaremos agora sobre os resultados dos questionários aplicados com os alunos. Dos 15 alunos entrevistados a maior parte mora na Vila Cauhy, seguido de Núcleo Bandeirante e Park Way, há também uma parcela pequena morando em outras cidades satélites como Recanto das Emas e Santa Maria. 
Eles também entendem jornada ampliada como a escola que tem aulas nos dois turnos (turno matutino e turno contrário). Não entendem a função da educação integral que é a de propor disciplinas integradas que agreguem mais conhecimento e o quanto eles podem aprender com as atividades. Quando perguntado por que eles estão matriculados na jornada ampliada, grande parte respondeu que foi a mãe que matriculou. Eles gostam da educação integral, mas, acham cansativo. Eles apreciam as atividades oferecidas, o lanche, o almoço.

No questionário, foi perguntado sobre quais atividades eles faziam em casa quando não era aluno da educação integral e, conforme previsto, eles passavam a maior parte do tempo brincando na rua, seguido de brincar em casa, dormir e ajudar os pais em alguma atividade trabalhista respectivamente. Por último, eles falaram o que não gostam na jornada ampliada e a grande maioria não gostam das aulas convencionais que tem pela manhã, porque não gostam de acordar cedo e também não gostam dos monitores, porque segundo os próprios alunos, eles chamam a atenção deles o tempo todo.

Os resultados da observação foram colhidos através de observação ativa. Freqüentei as aulas no período matutino por três vezes e acompanhei até o final no período da tarde, fizemos a pausa para o almoço e conversei um pouco com alguns alunos. Sempre me chamavam de tia ou estagiária. Eles me tinham como algo bem atrativo, sempre que eu chegava à sala eles logo me olhavam todos entusiasmados. Na primeira vez tive a impressão que eles esperavam que eu trouxesse alguma atividade diferente. Pude observar que no período matutino as salas são dispostas como as tradicionais e o ensino também. A turma é comum às outras, as crianças ora prestam atenção na aula ora conversa, nada de diferente. A partir de 12:30, horário que o período matutino encerra, algumas crianças vão para suas casas e as que são matriculadas na jornada ampliada ficam para almoçar.

A escola tem um refeitório amplo, com bastantes mesas e cadeiras, a comida é servida de forma organizada em bandejas e sempre com uma fruta de sobremesa. Esperei as crianças almoçarem e conversei um pouco com algumas delas. Elas são cheias de perguntas, indagavam sobre o que eu estava fazendo, e expliquei, conforme a professora havia explicado a eles em sala, falei que estava fazendo trabalhos para a faculdade e que faria a monografia sobre a escola, ai novamente me perguntaram o que era monografia e expliquei. Voltei para o assunto da educação integral e elas não falavam muito, para elas é 
uma aula comum, só que funciona o dia todo. Disseram que às vezes chegam muito cansados em casa, mas que gostam de estar lá fazendo tanta coisa diferente.

Quando voltamos para o período vespertino que começaria às 14:00 horas, percebi que as turmas não eram as mesmas do matutino. Os alunos que observei na turma pela manhã foram misturados com alunos de outras idades e outras turmas. Em conversa com os monitores, eles me falaram que precisa juntar os alunos por falta de pessoal e de material. Mas de qualquer forma as atividades correram bem e sem problemas. Alguns participavam das aulas de basquete, outro grupo jogava xadrez, uma professora ensina as lições a alunos da turma de reforço e assim transcorria a jornada ampliada do CAIC-JKO. Ao final das atividades eles fazem um lanche e às 16 horas estavam liberados.

Foi possível perceber que a escola, mesmo não recebendo verba do governo especificamente para a educação integral, mantém bem a jornada ampliada e de forma organizada. Os alunos na medida do possível colaboram de forma positiva das atividades e tentam manter um clima amistoso entre eles na hora das atividades. Sobre os pais, é perceptível que a presença deles com mais freqüência na escola ajudaria muito o andamento do projeto.

A seguir é apresentada uma análise sobre todo este trabalho, que traz reflexões sobre o Programa Mais Educação, sobre os conceitos de escola de tempo integral e Educação Integral a fim de analisar os princípios adotados na escola para saber se a prática escolar do CAIC-JKO é realmente escola de educação integral ou apenas adotam a jornada ampliada como extensão do tempo em que os alunos passam na escola. 


\section{3 - DISCUSSÃO E ANÁLISE}

Aqui será feito um comparativo da Educação Integral da escola analisada e o Programa Mais Educação, este modelo será utilizado porque é o principal projeto de jornada ampliada do país e que tem dado certo nas escolas em que é utilizado. Será feito também um comparativo entre Educação Integral e escola de tempo integral, até se chegar ao ponto principal deste trabalho que é concluir o que acontece no CAIC-JKO.

As atividades de Educação Integral do CAIC-JKO são um pouco diferentes do Mais Educação, em vários aspectos. O principal ponto que deve ser levado em consideração é que as escolas onde se utiliza Mais Educação têm, em geral, o IDEB (Índice de Desenvolvimento da Educação Básica) baixo o que não é o caso do CAIC-JKO, e no geral as turmas inseridas no programa são de séries finais da educação básica ao passo que no Núcleo Bandeirante, a prioridade são as séries iniciais. Outro ponto forte é a utilização de outros espaços além da escola nas atividades, enquanto que no CAIC-JKO não se utiliza espaços externos à escola, uma vez que a mesma tem um ambiente bem amplo.

Observa-se também que há diferença na quantidade de refeições oferecidas, enquanto que o Mais Educação propõe quatro refeições, o CAIC-JKO consegue manter com dificuldade apenas três e quando a escola não consegue recursos financeiros necessários, eles oferecem apenas duas. Outro ponto relevante também, é o fato das atividades no primeiro funcionarem de segunda a sexta-feira das $8 \mathrm{~h}$ às $17 \mathrm{~h} 45 \mathrm{~min}$, e no segundo, como já dito neste trabalho, de segunda a quinta-feira, apenas quatro dias na semana, das $7 \mathrm{~h} 30 \mathrm{~min}$ às $16 \mathrm{~h}$, além de que também essas escolas recebem dinheiro exclusivo do governo através do FNDE (Fundo Nacional de Desenvolvimento para a Educação) ao passo que o CAIC-JKO não tem esse tipo de benefício.

Mas o que não se deve deixar de lado é que ambos os projetos tem uma preocupação em abordar conteúdos de forma integrada que contribuam para a formação completa do aluno. Nos casos pôde ser visto a preocupação de tratar de assuntos sobre meio-ambiente, cidadania, direitos humanos, aulas de reforço, esportes e lazer, inclusão digital, promoção da saúde e alimentação saudável. E, ambos os projetos são um ideal de educação pública de qualidade e de democracia no acesso e permanência na escola que se busca alcançar. Conforme Gouveia (2006, p.84) a Educação Integral é um mecanismo para 
garantir uma educação pública de qualidade. Para Lúcia Velloso Maurício (2004, p.43), a jornada ampliada deve ser capaz de promover a socialização, a instrução escolar e também a formação cultural.

Entendidas as diferenças e semelhanças dos dois projetos compreenderemos porque escola integral e escola de tempo integral são termos diferentes. Para a prática da educação integral é necessário que a escola seja de tempo integral, ou seja, conforme vimos, as aulas e atividades precisam acontecer durante dois turnos, percebe-se então que a segunda é condição necessária para a existência da primeira. A escola integral deve ser capaz de ensinar as disciplinas de forma contextualizada, por isso não basta somente funcionar em dois turnos. De acordo com (Gadotti, 2009) a integralidade é um conceito pedagógico onde:

"O ensino da língua portuguesa e da matemática não está separado da educação emocional e da formação para a cidadania. Na educação integral, a aprendizagem é vista sob uma perspectiva holística." (Gadotti 2009, p. 4142).

Visto assim, é necessário que a aprendizagem na educação integral não seja reduzida a meros ensinos tradicionais que não valorizem a integração entre as disciplinas e que façam os conteúdos abordados "conversarem entre si" como um todo e não fragmentado. A educação que busca a integração entre as disciplinas ensinadas deve ser princípio norteador de todo o currículo que leve em conta todas as dimensões do ser humano, formando alunos por completo.

Passemos agora para as considerações finais. A educação integral do Mais Educação é princípio norteador para esta modalidade de ensino, logo percebemos que o CAIC-JKO não trabalha da mesma forma que este projeto. Apontamos vários pontos acima que o diferem e percebemos que há poucas convergências como o caso da busca por uma educação de qualidade. Não podemos deixar de lado o esforço do CAIC-JKO em defender e almejar uma educação pública que seja eficiente e que contribua de alguma forma para a melhoria das condições sociais do nosso país.

O que vale ressaltar é que a escola, objeto de estudo neste trabalho, atua com uma escola de tempo integral, e não necessariamente uma escola de educação integral. Percebemos isso quando da análise da bibliografia utilizada neste trabalho refletimos sobre alguns pontos, a saber: 
O projeto do CAIC-JKO aparenta ter caráter assistencial que busca compensar deficiências familiares da sociedade, como é o caso dos antigos CIEPS que:

“Foram criados (...) como um 'Programa Especial de Educação'(...) com o objetivo de atender crianças provenientes de famílias de baixa renda, sem o qual estariam condenadas à exclusão social.” (GADOTTI, 2009, p. 30).

Outro ponto observado é quando Gadotti (2009, p.32) nos diz que as escolas de tempo integral estão mais preocupadas em apenas estender o direito de "passar mais tempo na escola" às camadas mais pobres da população. Para ele, as escolas privadas já são de tempo integral, pois os alunos dispõem de tempo integral para se dedicar a sua educação, seja na escola, no seio familiar, nos cursos que freqüentam de inglês, esportes, lazer, artes, etc. Daí a necessidade, segundo ele, da escola pública precisar ser não só de tempo integral, mas principalmente integrada e integradora.

Mais uma questão que observamos no CAIC-JKO é a ausência da família na participação dos destinos da escola. A educação integral que funcione e tenha êxito deve contar com a participação da família no cotidiano escolar, e conforme constatamos em pesquisa, as famílias desses alunos não podem e não têm tempo para atuar nas decisões da escola e do dia a dia de seus filhos. Igualmente, a educação integral, precisa ampliar os espaços de aprendizagem e integrar escola-comunidade de maneira que o conhecimento seja mútuo, como vimos a escola não alcançou ainda esse ideal.

De todo o exposto, podemos notar que a prática de jornada ampliada da escola em questão se assemelha mais a escola de tempo integral do que educação integral propriamente dita. Lembrando que não estamos aqui para criticar, e sim analisar. Vários pontos puderam ser observados o que fez concluir que a escola além de não utilizar o Programa Mais Educação, também a escola não está incluída em vários itens que a faz se inserir no rol de escolas de educação integral. 


\section{CONSIDERAÇÕES FINAIS}

Este trabalho foi responsável por proporcionar momentos de aprendizado e troca de informações valiosas para a minha prática pedagógica. Através das visitas à escola, das pesquisas e observações tive como conhecer e conviver com o meio educativo e entender como funciona o cotidiano escolar da educação integral.

Foi possível compreender através deste trabalho o conceito verdadeiro da Educação Integral e seu sentido. Entender essa modalidade de forma reduzida como algo relacionado a tempo apenas, não deve ser a conduta correta de um futuro pedagogo. A jornada ampliada, como vimos, vai além do tempo e também atravessa espaços. Ela precisa de tempo sim para poder ser posta em prática, mas busca principalmente um ensino total.

Sabemos também que a escola integral deve explorar espaços distintos e fugir do cotidiano da escola. É necessária a integração da comunidade, do parque, da quadra de esportes, da praça, da prefeitura, das ruas, e dos demais atores que compõem este cenário que é tão vasto. A educação integral é um campo passível de diversas trocas de conhecimentos que defende uma valorização da escola e do aprendizado e que também nos faz refletir sobre nossos direitos como cidadãos e como pessoas em constante aprendizado.

Nessa experiência conheci profissionais dedicados que levantam a bandeira da jornada ampliada com afinco, mas que infelizmente percebem seus sonhos distantes pelo fato da escola não poder colocá-los todos em prática devido à falta e recursos, como sabemos é um problema que a grande maioria das escolas brasileiras enfrenta. Estudar a educação integral é uma atividade enriquecedora para os pedagogos da nossa atualidade, uma vez que tal empreita deveria ser a meta de todas as escolas brasileiras.

A educação integral deve ser meta de todos os governos e escolas que efetivamente são preocupadas com os destinos de nossas crianças, pois é muito mais vantajoso deixá-las

na escola aprendendo e ensinando também, cada uma com sua vivência, do que assistir a marginalização da escola e de seus alunos que em grande parte não têm tarefas no turno contrário ao da aula e a única opção que lhe sobre e brincar na rua e se envolverem com situações impróprias para suas idades.

Fica aqui o meu apelo a todos nós educadores interessados num futuro melhor para o nosso país, precisa-se entender e querer a educação integral nas nossas escolas. È 
necessário conhecê-la e testá-la para que possamos utilizar melhor os espaços educativos e os conhecimentos abordados no ensino das escolas, precisamos aproveitar melhor o potencial dos alunos e principalmente envolver a comunidade em todo esse processo. 


\section{PROJETO DE ATUAÇÃO PROFISSIONAL}

Tudo quanto é grande acredito eu, não é só dom natural ou resultado da época. Mas é também resultado do nosso esforço e da nossa perseverança.

Leonardo da Vinci

O curso de pedagogia nos oferece uma gama de opções para nossa futura prática pedagógica. Dentro das possibilidades de atuação, tenho dois projetos que gostaria de por em prática, um ou outro, após graduada. O primeiro é atuar como pedagoga de algum órgão público e o segundo pode acontecer com a minha atual ocupação de Agente Social na Secretaria de Desenvolvimento Social e Transferência de Renda - SEDEST. A Sedest é a Secretaria de Estado do Governo do Distrito Federal responsável pela Assistência Social do DF e também pela transferência de renda do Governo Federal para o Distrito Federal.

Quando aprovada como pedagoga em algum órgão público gostaria de trabalhar com reciclagem, como dito no meu memorial já trabalhei na CAESB (Companhia de Saneamento Ambiental do Distrito Federal) nesse campo de atuação. Minha idéia é fazer palestras para conscientizar as pessoas sobre o excesso e acúmulo de resíduos sólidos no nosso planeta bem como os malefícios dessa atividade. Para isso, darei prioridade a concursos em secretarias ou empresas públicas que tenham uma preocupação ambiental, como é o caso da CAESB.

Uma outra opção também é atuar como pedagoga na própria Secretaria que trabalho. A SEDEST tem centros de atendimento às crianças que se chamam CENTROS DE ORIENTAÇÃO SOCIOEDUCATIVA - COSE’s. Lá as crianças vão a horários contrários aos das aulas escolares para participarem de atividades complementares ao seu aprendizado, para isso tem aulas de reforço, brincadeiras, esportes, música, alimentação saudável. No geral, são crianças carentes de baixa renda que não tem oportunidades de acesso a culturas, que sofrem ou sofreram algum tipo de violação de direitos.

Minha idéia central seria trabalhar com essas crianças a questão de valores e autoestima, esses temas seriam incorporados às atividades cotidianas que eu teria que trabalhar com as crianças como as citadas acima. O meu foco em valores e auto-estima seria valorizar a cultura de cada criança e principalmente, conscientizá-las que elas são 
portadoras de direitos iguais perante a sociedade. Com isso, busca-se melhorar a autoestima das mesmas com atividades e oficinas que busquem e valorizem isso.

Por fim, espero conseguir alcançar meus objetivos e que como pedagoga eu possa contribuir de forma positiva para melhoria de vida de nossas crianças e de nosso planeta. Numa profissão que às vezes é tão difícil, como é o caso dos professores da educação infantil, que eu consiga me realizar como profissional de verdade. 


\section{REFERÊNCIAS}

BRASIL. Constituição (1988). Constituição da República Federativa do Brasil. Brasília-DF: Senado Federal, 2010.

BRASIL. Decreto n. ${ }^{\mathbf{7}} \mathbf{7 . 0 8 3}$, de 27 de janeiro de 2010. Dispõe sobre o Programa Mais Educação. Diário Oficial do Distrito Federal

BRASIL. Estatuto da Criança e do Adolescente. Edição: 5. ed.rev. atual. Brasília: Câmara dos Deputados, Coordenação de Serviços Gráficos, 2006.

BRASIL. Lei de Diretrizes e Bases da Educação Nacional. 5 ed. Brasília: Câmara dos Deputados, Centro de Documentação e Informação, 2010.

BRASIL. Ministério da Educação. Educação integral/educação integrada e $(m)$ tempo integral: concepções e práticas na educação brasileira Mapeamento das experiências de jornada escolar ampliada no Brasil. Brasília, DF: MEC, 2009.

CAIC JUSCELINO KUBITSCHEK DE OLIVEIRA. Projeto Político Pedagógico. Brasília, 2010.

COELHO, Lígia Martha Coimbra da Costa; CAVALIERE, Ana Maria Vilela (organizadoras). Educação brasileira e(m) tempo integral. Rio de Janeiro: Vozes, 2002.

GADOTTI, Moacir. Educação Integral: inovações em processo. São Paulo: Instituto Paulo Freire, 2009.

GOUVEIA, Maria Júlia Azevedo. Educação Integral com a infância e a juventude. Cadernos Cenpec, São Paulo, n.2, p.77-85, 2. Sem. 2006. Edição especial sobre Educação integral.

MINISTÉRIO DA EDUCAÇÃO. Série Mais Educação - Educação Integral, Texto Referência para o debate nacional. Brasília, 2010. Disponível em portal.mec.gov.br/dmdocuments/cad_mais_educacao_2.pdf. Acesso em 20/05/2011.

MAURÍCIO, Lúcia Velloso. Escola pública de horário integral: demanda expressa pela representação social, 2001. Tese (Doutoramento) - Universidade Estadual do Rio de Janeiro, Rio de Janeiro, 2001.

MOLL, J. Histórias de Vida, histórias de escola: elementos para uma pedagogia da cidade. Petrópolis: Vozes, 2000.

TEIXEIRA, Anísio. Centro Educacional Carneiro Ribeiro. Revista Brasileira de Estudos Pedagógicos. Rio de Janeiro, v. 31, n.73, jan./mar, p. 78-84, 1959. 
http://portal.mec.gov.br/index.php?Itemid=86\&id=12372\&option=com_content\&view=arti cle acesso em 19 de abril de 2011.

http://alceniguerra.com.br/portal acesso em 20 de abril de 2011.

http://www.sedest.df.gov.br/ acesso em 20 de abril de 2011.

http://www.cultura.gov.br/site/2007/05/07/programa-mais-educacao/visita em 13/09/2011 acesso em 20 de abril de 2011.

http://www.bandeirante.df.gov.br/ acesso em 15 de setembro de 2011.

http://www.forumeja.org.br/df/?q=node/359 acesso em 05 de agosto de 2011.

http://portal.mec.gov.br/index.php?Itemid=86\&id=12372\&option=com_content\&view=arti cle acesso em 05 de agosto de 2011.

http://portal.inep.gov.br/web/portal-ideb/portal-ideb acesso em 03 de novembro de 2011. 